\title{
Estimates of Public-Supply, Domestic, and Irrigation Water Withdrawal, Use, and Trends in the Upper Rio Grande Basin, 1985 to 2015
}

Scientific Investigations Report 2021-5036 
Covers. Rio Grande in the Rio Grande Gorge, at the Rio Grande del Norte National Monument, Cerro, New Mexico. [Photograph by Pearle Sandstrom-Smith, January 2015, used with permission.] Irrigation water discharged to canal in the San Luis Valley near Monte Vista, Colorado. [Photograph by Pearle Sandstrom-Smith, June 2013, used with permission.] Center pivot irrigation in the San Luis Valley near Monte Vista, Colorado. [Photograph by Pearle Sandstrom-Smith, June 2013, used with permission.] Flood irrigated cotton field near El Paso, Texas. [Photograph by Lori Duran, U.S. Geological Survey, July 2017.] Wooden acequia providing irrigation water supply, Las Trampas, New Mexico. [Photograph by Tamara Ivahnenko, U.S. Geological Survey, November 2017.] Rio Grande Gorge, at the Rio Grande del Norte National Monument, Cerro, New Mexico. [Photograph by Rick Clawges, U.S. Geological Survey, November 2016.] 


\section{Estimates of Public-Supply, Domestic, and Irrigation Water Withdrawal, Use, and Trends in the Upper Rio Grande Basin, 1985 to 2015}

By Tamara I. Ivahnenko, Allison K. Flickinger, Amy E. Galanter, Kyle R.

Douglas-Mankin, Diana E. Pedraza, and Gabriel B. Senay

Scientific Investigations Report 2021-5036 


\section{U.S. Geological Survey, Reston, Virginia: 2021}

For more information on the USGS - the Federal source for science about the Earth, its natural and living resources, natural hazards, and the environment—visit https://www.usgs.gov or call 1-888-ASK-USGS.

For an overview of USGS information products, including maps, imagery, and publications, visit https://store.usgs.gov/.

Any use of trade, firm, or product names is for descriptive purposes only and does not imply endorsement by the U.S. Government.

Although this information product, for the most part, is in the public domain, it also may contain copyrighted materials as noted in the text. Permission to reproduce copyrighted items must be secured from the copyright owner.

Suggested citation:

Ivahnenko, T.I., Flickinger, A.K., Galanter, A.E., Douglas-Mankin, K.R., Pedraza, D.E., and Senay, G.B., 2021, Estimates of public-supply, domestic, and irrigation water withdrawal, use, and trends in the Upper Rio Grande Basin, 1985 to 2015: U.S. Geological Survey Scientific Investigations Report 2021-5036, 31 p., https://doi.org/10.3133/sir20215036.

Associated data for this publication:

Ivahnenko, Tamara, and Galanter, A.E., 2021, Estimated use of water by subbasin (HUC8) in the Upper Rio Grande Basin, 1985-2015: U.S. Geological Survey data release, https://doi.org/10.5066/F7SX6CJ2.

Pedraza, D.E., Stengel, V.G., Pasley, N., and Pease, E.C., 2019, 2015 irrigated acres feature class for the Upper Rio Grande Basin, New Mexico, Texas, United States and Chihuahua, Mexico: U.S. Geological Survey data release, https://doi.org/10.5066/P990IFYY.

Sargent, B.P., Houston, N.A., and Heal, E.N., 2020, Estimated use of water by subbasin (HUC8) in the Red River Basin, 2010 and 2015: U.S. Geological Survey data release, https://doi.org/10.5066/P9S01Y3T.

ISSN 2328-0328 (online) 


\section{Acknowledgments}

The authors thank the contributions of data and review expertise from the U.S. Geological Survey Water Use Specialists in each of the Water Science Centers for Colorado, New Mexico, and Texas, who compiled information for this report using data from many State, local, Federal agencies, and nongovernment entities. Without their dedication and attention to the details of water-use data collection and analysis, this report would not be possible. 



\section{Contents}

Acknowledgments ……...................................................................................................................

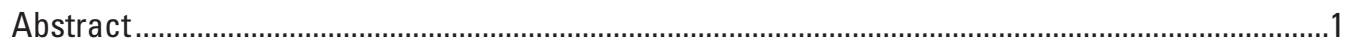

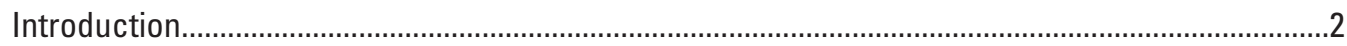

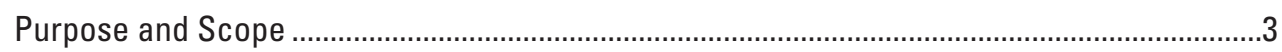

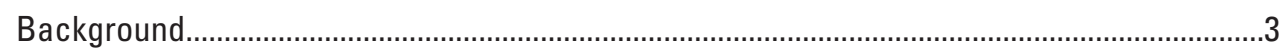

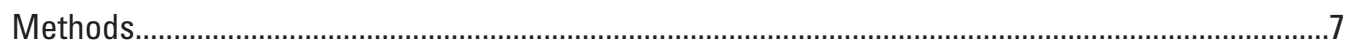

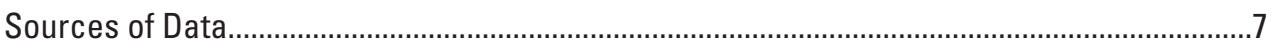

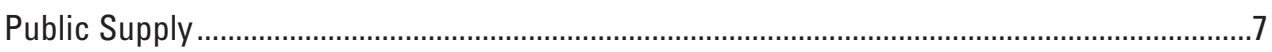

Self-Sup

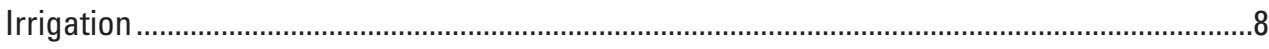

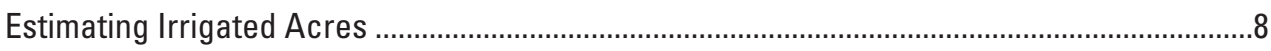

Estimating Evapotranspiration................................................................................................

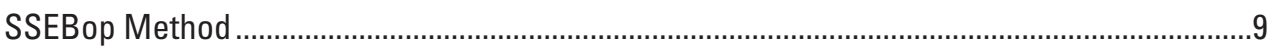

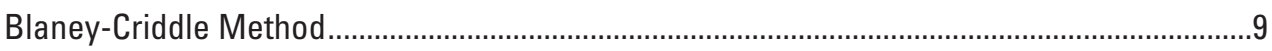

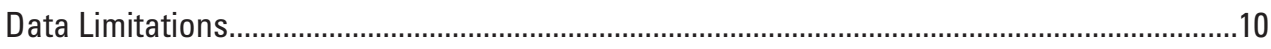

Total Water Withdrawals, Public-Supply, Domestic, and Irrigation Water Withdrawals,

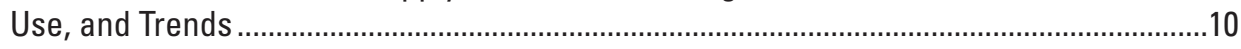

Total Water Withdrawals for 2015....................................................................................... 10

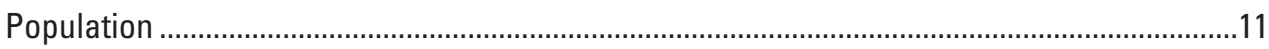

Public Supply and Self-Supplied Domestic .....................................................................11

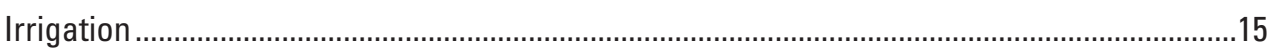

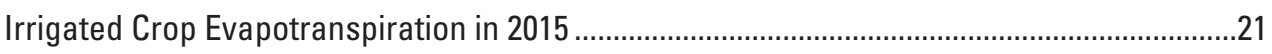

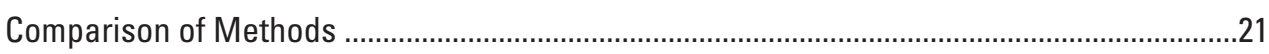

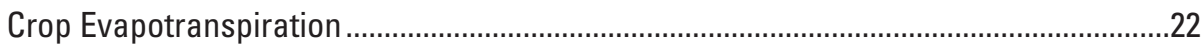

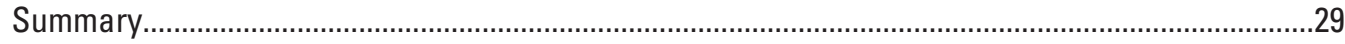

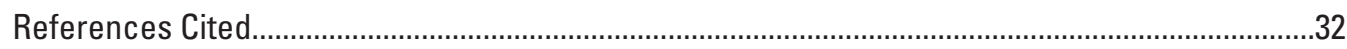

\section{Figures}

1. Map showing location of the Upper Rio Grande Basin study area...................................5

2. Graph showing total 2015 water withdrawals in the Upper Rio Grande Basin study area by water-use category......

3. Graph showing left y-axis shows the population of states and Ciudad Juarez, United Mexican States, located within the Upper Rio Grande Basin. Right $y$-axis shows the total population in the Upper Rio Grande Basin study area, 1985-2015.

4. Graph showing left y-axis shows water withdrawals by source, total water withdrawals, and public-supply deliveries. Right y-axis shows the public-supply population in the Upper Rio Grande Basin study area, 1985-2015............14

5. Graph showing left y-axis shows irrigation withdrawals by source and total water withdrawals. Right y-axis shows total number of irrigated acres in the Upper Rio Grande Basin study area, 1985-2015.

6. Map showing irrigated acres in the Upper Rio Grande Basin study area in 2015..........19 
7. Graphs showing irrigated acres by system type and total irrigated acres for $A$, Colorado; $B$, New Mexico; and C, Texas in the Upper Rio Grande Basin study area, 1985-2015

8. Map showing Operational Simplified Surface Energy Balance (SSEBop) model estimates of annual evapotranspiration in the Upper Rio Grande Basin study area, 2015 . 23

9. Map showing annual evapotranspiration for 2015 in the San Luis Valley, Colorado ......30

\section{Tables}

1. Annual mean precipitation for the eight-digit hydrologic unit code subbasins in the Rio Grande Basin study area, 1985-2015.

2. Annual mean streamflow in the upper, middle, and lower Upper Rio Grande Basin study area, 1985-2015.

3. Summary of data used to parameterize the Operational Simplified Surface Energy Balance (SSEBop) model.

4. Total water withdrawals for the Upper Rio Grande Basin study area and States, by source, for the States in the Upper Rio Grande Basin study area, 2015

5. Population in the parts of the States in the Upper Rio Grande Basin study area and Ciudad Juarez, United Mexican States, 1985-2015.

6. Public-supply withdrawals, by source, and deliveries to domestic use, self-supply domestic withdrawals, total domestic use, and domestic per-capita use for populations served from public suppliers and self-supplied populations in the Upper Rio Grande Basin study area, 1985-2015.

7. Public-supply withdrawals, by source, deliveries to domestic use, and domestic per-capita use for populations served from public suppliers for the parts of the States in the Upper Rio Grande Basin study area, 1985-2015

8. Irrigation withdrawals, source water, consumptive use, and irrigated acres by system type in the Upper Rio Grande Basin study area, 1985-2015

9. Irrigation withdrawals, source water, consumptive use, and irrigated acres by system type for the parts of the States in the Upper Rio Grande Basin study area, 1985-2015

10. Comparison of consumptive water-use estimates at an 8-digit hydrologic unit code (HUC-8) spatial resolution

11. Operational Simplified Surface Energy Balance (SSEBop) model estimates of actual evapotranspiration and irrigated acres by crop and 8-digit hydrologic unit code in the Upper Rio Grande Basin study area, 2015.

12. Operational Simplified Surface Energy Balance (SSEBop) model estimates of actual evapotranspiration and irrigated acres for alfalfa by irrigation system type in select 8-digit hydrologic unit codes in the Upper Rio Grande Basin study area, 2015 


\section{Conversion Factors}

U.S. customary units to International System of Units

\begin{tabular}{|c|c|c|}
\hline Multiply & By & To obtain \\
\hline \multicolumn{3}{|c|}{ Length } \\
\hline inch (in.) & 2.54 & centimeter $(\mathrm{cm})$ \\
\hline inch (in.) & 25.4 & millimeter $(\mathrm{mm})$ \\
\hline foot $(\mathrm{ft})$ & 0.3048 & meter $(\mathrm{m})$ \\
\hline mile (mi) & 1.609 & kilometer (km) \\
\hline \multicolumn{3}{|c|}{ Area } \\
\hline acre & 0.4047 & hectare (ha) \\
\hline acre & 0.004047 & square kilometer $\left(\mathrm{km}^{2}\right)$ \\
\hline square mile $\left(\mathrm{mi}^{2}\right)$ & 259.0 & hectare (ha) \\
\hline square mile $\left(\mathrm{mi}^{2}\right)$ & 2.590 & square kilometer $\left(\mathrm{km}^{2}\right)$ \\
\hline \multicolumn{3}{|c|}{ Volume } \\
\hline cubic foot $\left(\mathrm{ft}^{3}\right)$ & 0.02832 & cubic meter $\left(\mathrm{m}^{3}\right)$ \\
\hline gallon (gal) & 0.003785 & cubic meter $\left(\mathrm{m}^{3}\right)$ \\
\hline million gallons (Mgal) & 3,785 & cubic meter $\left(\mathrm{m}^{3}\right)$ \\
\hline acre-foot (acre-ft) & 1,233 & cubic meter $\left(\mathrm{m}^{3}\right)$ \\
\hline acre-foot (acre-ft) & 0.001233 & cubic hectometer $\left(\mathrm{hm}^{3}\right)$ \\
\hline thousand acre-foot (taf) & 1,000 & million acre-foot (maf) \\
\hline \multicolumn{3}{|c|}{ Flow rate } \\
\hline acre-foot per year (acre-ft/yr) & 1,233 & cubic meter per year $\left(\mathrm{m}^{3} / \mathrm{yr}\right)$ \\
\hline acre-foot per year (acre-ft/yr) & 0.001233 & cubic hectometer per year $\left(\mathrm{hm}^{3} / \mathrm{yr}\right)$ \\
\hline foot per second (ft/s) & 0.3048 & meter per second $(\mathrm{m} / \mathrm{s})$ \\
\hline $\begin{array}{l}\text { cubic foot per second per square } \\
\text { mile }\left([\mathrm{ft} 3 / \mathrm{s}] / \mathrm{mi}^{2}\right)\end{array}$ & 0.01093 & $\begin{array}{l}\text { cubic meter per second per square kilometer } \\
\qquad\left(\left[\mathrm{m}^{3} / \mathrm{s}\right] / \mathrm{km}^{2}\right)\end{array}$ \\
\hline cubic foot per day (ft3/d) & 0.02832 & cubic meter per day $\left(\mathrm{m}^{3} / \mathrm{d}\right)$ \\
\hline gallon per minute (gal/min) & 0.06309 & liter per second $(\mathrm{L} / \mathrm{s})$ \\
\hline gallon per day (gal/d) & 0.003785 & cubic meter per day $\left(\mathrm{m}^{3} / \mathrm{d}\right)$ \\
\hline cubic foot per second $\left(\mathrm{ft}^{3} / \mathrm{s}\right)$ & 0.02832 & cubic meter per second $\left(\mathrm{m}^{3} / \mathrm{s}\right)$ \\
\hline
\end{tabular}

Temperature in degrees Celsius $\left({ }^{\circ} \mathrm{C}\right)$ may be converted to degrees Fahrenheit $\left({ }^{\circ} \mathrm{F}\right)$ as

$$
{ }^{\circ} \mathrm{F}=\left(1.8 \times{ }^{\circ} \mathrm{C}\right)+32 .
$$

Temperature in degrees Fahrenheit $\left({ }^{\circ} \mathrm{F}\right)$ may be converted to degrees Celsius $\left({ }^{\circ} \mathrm{C}\right)$ as

$$
{ }^{\circ} \mathrm{C}=\left({ }^{\circ} \mathrm{F}-32\right) / 1.8 \text {. }
$$

\section{Datum}

Vertical coordinate information is referenced to the North American Vertical Datum of 1988 (NAVD 88).

Horizontal coordinate information is referenced to the North American Datum of 1983 (NAD 83).

Elevation, as used in this report, refers to distance above the vertical datum. 


\section{Abbreviations}

$\begin{array}{ll}\text { Reclamation } & \text { Bureau of Reclamation } \\ \text { CIR } & \text { crop irrigation coefficient } \\ \text { ET } & \text { evapotranspiration } \\ \text { ETa } & \text { actual evapotranspiration } \\ \text { ETo } & \text { reference evapotranspiration } \\ \text { FAS } & \text { focus area study } \\ \text { GIS } & \text { geographic information system } \\ \text { gpcd } & \text { gallons per-capita daily } \\ \text { HUC } & \text { hydrologic unit code } \\ \text { in/yr } & \text { inch per year } \\ \text { MBC } & \text { Modified Blaney-Criddle } \\ \text { MODIS } & \text { Moderate Resolution Imaging Spectroradiometer } \\ \text { NAIP } & \text { National Agricultural Imagery Program } \\ \text { NASS } & \text { National Agriculture Statistics Service } \\ \text { NWIS } & \text { National Water Information System } \\ \text { NWC } & \text { National Water Census } \\ \text { OBC } & \text { Original Blaney-Criddle } \\ \text { SECURE } & \text { Science and Engineering to Comprehensively Understand and } \\ \text { SSEBop } & \text { Responsibly Enhance } \\ \text { URGB } & \text { Operational Simplified Surface Energy Balance model } \\ \text { USDA } & \text { Upper Rio Grande Basin } \\ \text { USGS } & \text { U.S. Department of Agriculture } \\ \text { U.S. Geological Survey }\end{array}$




\title{
Estimates of Public-Supply, Domestic, and Irrigation Water Withdrawal, Use, and Trends in the Upper Rio Grande Basin, 1985 to 2015
}

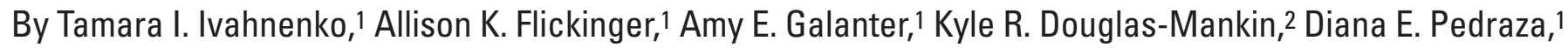 \\ and Gabriel B. Senay ${ }^{1}$
}

\section{Abstract}

The Rio Grande flows approximately 670 miles from its headwaters in the San Juan Mountains of south-central Colorado to Fort Quitman, Texas, draining the Upper Rio Grande Basin (URGB) study area of 32,000 square miles that includes parts of Colorado, New Mexico, and Texas. Parts of the basin extend into the United Mexican States (hereafter "Mexico"), where the Rio Grande forms the international boundary between Texas and the State of Chihuahua, Mexico. The URGB was chosen as a focus area study (FAS) for the U.S. Geological Survey (USGS) National Water Census (NWC) as part of the WaterSMART initiative. The objective of the USGS NWC under WaterSMART is to focus on the technical aspects of providing information and tools to stakeholders so that they can make informed decisions on water availability.

This report contains water-use withdrawal estimates of groundwater and surface water for public-supply, self-supplied domestic, and irrigation water use for years 1985-2015 at 5 -year intervals for the 22 drainage basins at the subbasin 8-digit hydrologic unit code (HUC-8) level. Data for additional categories of self-supplied industrial, mining, livestock, aquaculture, thermoelectric, and hydroelectric water use are provided in the accompanying data release to illustrate total withdrawals for the URGB. The additional category data are provided in this report only for the year 2015. Deliveries of water from public-supply systems to domestic users are included and are the only water-delivery data presented in this report. Consumptive use for irrigation is reported for all HUC-8 subbasins for 2015 and for select HUC-8s in the other years beginning in 1985 (the irrigation category includes irrigation for both crop and golf). Water transported outside of the URGB (interbasin transfers) is not included as part of the withdrawals and are not accounted for in any category of use within the URGB.

\footnotetext{
1U.S. Geological Survey.
}

${ }^{2}$ U.S. Department of Agriculture.
Estimated total withdrawals for all the water-use categories (including hydroelectric) in 2015 as reported in the USGS compilations in the URGB were 3,152.10 million gallons per day $(\mathrm{Mgal} / \mathrm{d})$. Surface water was the dominant source of water used in the URGB, providing about 71 percent of total withdrawals. Nearly all withdrawals were from freshwater sources; there was a small amount of saline groundwater that was used for public supply and self-supplied industrial, which were all reported in Texas. The proportions of total 2015 withdrawals from States in the URGB are 46 percent each in Colorado and New Mexico and 8 percent in Texas. A comparison of 2015 water withdrawals for the URGB - for the categories of public supply, self-supplied domestic, self-supplied industrial, thermoelectric, irrigation, livestock, mining, aquaculture, and hydroelectric - showed that irrigation is the dominant water use, at 74 percent of total withdrawals. Other water-use categories in the URGB that use about 1 percent or greater of the total water use by volume are public supply ( 9 percent) and self-supplied domestic and aquaculture (each about 1 percent). This report focuses on the higher volume, consumptively used categories of public supply, self-supplied domestic, and irrigation. A discussion on basin population provides context for the categories of public-supply and self-supplied domestic water use.

The population in the part of the basin in the United States grew from 1.36 to 2.26 million people between 1985 and 2015. With the city of Ciudad Juarez, Chihuahua, Mexico, included, the total population of the URGB grew from an estimated 2.01 to 3.66 million people between 1985 and 2015 . The largest concentrations of population are in New Mexico, Texas, and Chihuahua, with 98 percent of the total number of people in the basin in 1985 and 99 percent of the total in 2015 residing in these states. Albuquerque, El Paso, and Ciudad Juarez are the largest cities in the basin.

Total withdrawals for public supply in the URGB averaged $277 \mathrm{Mgal} / \mathrm{d}$ from 1985 to 2015 . About 60 percent of the URGB total public-supply withdrawals occurred in New Mexico, which averaged $170 \mathrm{Mgal} / \mathrm{d}$. Groundwater provided 92 and 70 percent of the total withdrawals for public supply in 1985 and 2015 , respectively. Deliveries to domestic users from public 
suppliers are reported for all drainage basins and years, and account for part of the total public-supply withdrawals. In the URGB, domestic deliveries from public suppliers increased from 1985 to 1995; since 2005, domestic deliveries from public supply have declined. The total populations served by public suppliers in the URGB increased by 90 percent from 1985 to 2015. In the URGB, more people were served by publicsupply systems than were self-supplied, and the percentage of people on public-supply systems ranged from 81 to 92 percent from 1985 to 2015. Total domestic withdrawals in the URGB (deliveries plus self-supply withdrawals) ranged from 177.49 to $234.83 \mathrm{Mgal} / \mathrm{d}$ and peaked in 2005. Domestic use decreased from 2005 to 2010 by 17 percent and remained less than $200 \mathrm{Mgal} / \mathrm{d}$ in 2015. The per-capita daily use for the entire URGB fluctuated between the reporting years, but overall, domestic per-capita use across the basin has declined 46 percent from 145 gallons per capita daily (gpcd) in 1985 to 79 gpcd in 2015 .

Total irrigation withdrawals in the URGB had a mean value of 2,767.66 Mgal/d from 1985 to 2015 and withdrawals peaked in 1995 at 3,416.84 Mgal/d. Over the 30-year period, irrigation source water in the URGB has ranged from 69 to 84 percent surface water, and the most surface water diverted in the basin for irrigation was in 1995. Groundwater withdrawals for irrigation have fluctuated but overall decreased by 13 percent between 2005 and 2015. Slightly more than one-half of total irrigation withdrawals within the URGB occurred in Colorado, with a mean of 57 percent from 1985 to 2015 . From the peak of water withdrawals in 1995 to the conclusion of this study in 2015, total irrigation withdrawals across the study area decreased by 32 percent.

The total number of irrigated lands in the URGB from 1985 to 2015 had a mean of about 800 thousand acres, and more irrigated lands were consistently located in the headwaters of the URGB in the San Luis Valley, Colorado than the remainder of the study basin. In the 30-year period, Colorado had a mean of 68 percent of total irrigated lands whereas irrigated acres in New Mexico had a mean of 26 percent and the remaining 7 percent were in Texas. Since 2000, the number of irrigated acres in the URGB has fluctuated, but overall has decreased by 12 percent.

More land was irrigated with surface systems (surface irrigation includes flood, furrow, and gated pipe systems, hereafter collectively termed "surface") in the URGB than with other irrigation system types. Across the 30 -year period, from 62 to 88 percent of total irrigated lands had surface-system irrigation, and surface systems covered a mean of 69 percent of the URGB's acres. Microirrigation systems, predominantly in New Mexico and Texas, compose 0.2 percent or less of the irrigated acres in the basin and were first reported in 1995. From 1985 to 2015, the surface systems decreased in the basin by about 38 percent, and the number of acres of sprinkler and microirrigation systems increased. Acres irrigated by sprinkler systems (predominately center pivot systems) have increased 179 percent from about 99 thousand acres in 1985 to 275 thousand acres in 2015. In this dataset, the number of sprinkler acres surpassed the number of surface irrigated acres in 2000.
Within the San Luis Valley in Colorado, the acreage of surface irrigation has decreased, and sprinkler irrigation has increased over the 30-year period. In the New Mexico part of the URGB, surface irrigation is reported as the dominant system type, where irrigation by surface systems accounts for 97-98 percent of how water is provided to crops. As in New Mexico, crops in Texas are irrigated primarily by surface systems.

The mean of the mean simulated actual evapotranspiration (ETa) for crops in 2015 across the basin was highest for durum wheat at an estimated 36.00 inches per year (in/yr), and lowest for vegetables at an estimated $19.48 \mathrm{in} / \mathrm{yr}$. Alfalfa and irrigated grass pastures mean ETa had a mean of 31.4 and $27.58 \mathrm{in} / \mathrm{yr}$, respectively, for the basin. Pecans and peppers, both signature crops in the Rio Grande Basin, each had a mean ETa of 30.67 and $30.38 \mathrm{in} / \mathrm{yr}$ of mean. In general, mean ETa values for crops were lower in the HUCs of the Colorado San Luis Valley (13010001, 13010002, 13010003 and 13010004) which are more northerly and at higher elevations. The mean ETa for crops increased in the HUCs that are more southerly and at lower elevations in the basin.

\section{Introduction}

Increasing demand for the limited water resources of the United States continues to put pressure on resource-management agencies to balance the competing needs of ecosystem health with municipal, agricultural, and other water uses. The U.S. Geological Survey (USGS) National Water Census (NWC) is a research program focused on water availability and use, called for in the SECURE Water Act and implemented through the Department of the Interior's (Sustain and Manage America's Resources for Tomorrow) WaterSMART initiative (https://www.doi.gov/watersmart). The overarching purpose of WaterSMART is to develop data and tools needed by resource managers to meet challenges imposed by increasingly limited water availability because of aging infrastructure, population growth, groundwater depletion, impaired water quality, water needs for human and environmental uses, and climate variability and change. The objective of the USGS NWC under WaterSMART is to focus on the technical aspects of providing information and tools to stakeholders so that they can make informed decisions on water availability (Water Availability and Use Science Program, 2020).

In 2014, the Upper Rio Grande Basin (URGB) of Colorado, New Mexico, Texas, and northern United Mexican States (hereafter "Mexico") was chosen as a focus area study (FAS) for the USGS NWC. The conjunctive use of water in the URGB takes place under a myriad of legal constraints including the Rio Grande Compact agreement between the States, administration of water rights by individual States, an international treaty with Mexico, and several Federal water projects. The conveyance and use of surface water in the URGB are achieved through an engineered system 
of reservoirs, diversions, and irrigation canals which deliver water to agricultural, residential, and industrial users. Groundwater is used for municipal and industrial purposes and supplements the agricultural water supply. As populations increase and agricultural cropping patterns change, demands for water are increasing. Additionally, the region is experiencing a decrease in its water supply because of drought and climate change (International Boundary and Water Commission, 2020). Additionally, the quality of available water is a primary factor that can limit its use and availability. The growing gap between supply and demand has resulted in continued conflict over water in the region and ongoing litigation between users and Federal, Tribal, State, and local agencies.

This report draws from the available water sources (groundwater or surface water) to provide a basin-specific summary of water uses for public supply, self-supplied domestic, and irrigation in 5-year increments from 1985 to 2015 , including analysis of trends over the entire 30 -year period. Data are presented at the 8-digit subbasin hydrologic unit code (HUC-8) (Seaber and others, 1987) level. The water-use categories of public supply, self-supplied domestic, and irrigation are the largest categories by volume in the URGB study area of the water-use categories for which the USGS collects data. Data for additional categories of self-supplied industrial, mining, livestock, aquaculture, thermoelectric, and hydroelectric are provided in the accompanying data release to illustrate total withdrawals for the URGB. The additional category data are provided in this report only for the year 2015 (Ivahnenko and Galanter, 2021). This report makes a substantial contribution to the USGS 5-year national compilation dataset (Water Use in the United States [https://www.usgs.gov/ mission-areas/water-resources/science/water-use-united-states? qt-science_center_objects $=0 \#$ qt-science_center_objects $]$ ), as well as the water budget (Upper Rio Grande Basin Focus Area Study [https://www.usgs.gov/centers/ot-water/science/ upper-rio-grande-basin-focus-area-study?qt-science_center _objects=0\#qt-science_center_objects]) by providing a summary of water uses aggregated by drainage basins.

\section{Purpose and Scope}

The purpose of this report is to present estimates of public-supply, self-supplied domestic, and irrigation water use for 1985-2015 at 5-year intervals for the 22 drainage basins at the HUC-8 level in the URGB. In addition to the three water-use categories, self-supplied industrial, mining, livestock, aquaculture, thermoelectric, and hydroelectric water use estimates at the HUC- 8 level for 2015 are presented to illustrate total withdrawals for the basin. Water withdrawals for all the water-use categories 1985-2015 are provided in a data release (Ivahnenko and Galanter, 2021); however, water use data for public-supply, self-supplied domestic and irrigation are tabulated and presented in this report. Withdrawal data for 2015 water-use categories of self-supplied industrial, mining, livestock, aquaculture, thermoelectric, and hydroelectric are tabulated and presented only in the data release. The withdrawals represent groundwater and surface water for the categories of use. Deliveries of water from public-supply systems to domestic users are included and are the only water-delivery data presented in this report. Consumptive use and conveyance losses are reported for nearly all HUC-8s for all the years for irrigation (the irrigation category includes irrigation for both crop and golf).

All drainage basins (HUC-8) that are in the URGB, which includes parts of Colorado, New Mexico, and Texas, are presented as the geographic areas for which mean daily withdrawals from groundwater and surface water (fresh and saline) are tabulated for each category of use, in units of million gallons per day (Mgal/d), for 7 calendar years (1985, 1990, 1995, 2000, 2005, 2010, and 2015). Data are summarized and presented here for the HUC-8s and by States. Water transported outside of the URGB (interbasin transfers) is not included as part of the withdrawals and is not accounted for in any category of use within the URGB. Other data include irrigated acres, total population, as well as population served by public-supply systems and self-supplied domestic users. Population data represent the population within the HUC-8 boundaries within the URGB and are summarized by State. Limited information on population numbers is provided for the state of Chihuahua, Mexico.

In addition to reporting the irrigation consumptive use for selected HUC-8s as calculated through Original Blaney-Criddle (OBC) and Modified Blaney-Criddle (MBC) methods for the years 1985 through 2015, actual evapotranspiration (ETa) for 2015 (for all HUC-8s) is reported as consumptive use based on Landsat satellite data and the Operational Simplified Surface Energy Balance (SSEBop) model. A comparison of the 2015 SSEBop, OBC, and Moderate Resolution Imaging Spectroradiometer (MODIS) consumptive use is presented. A geographic information system (GIS) datalayer for 2015 irrigated acres developed for the URGB for New Mexico, Texas, and Mexico based on satellite images was used to identify the irrigated acres in the URGB for the SSEBop evapotranspiration analysis. This datalayer of irrigated acres is provided as a data release (Pedraza and others, 2019).

\section{Background}

One of the goals of the NWC (National Water Census: Water Use [https://www.usgs.gov/mission-areas/ water-resources/science/national-water-census-water-use? qt-science_center_objects $=0 \# q$ qt-science_center_objects])is to develop and improve national estimates of water-budget components at consistent spatial (drainage basin HUC-8 or HUC-12) and temporal (monthly, daily) scales. The NWC is working to achieve this goal through a series of studies designed to quantify the amount of water that resides in or moves through an FAS. Development of estimates of the selected water-budget components (precipitation, streamflow, groundwater, and evapotranspiration), as well as water use for the URGB FAS, 
will support current and on-going local, State, and Federal efforts to advance the understanding of the hydrologic system of the URGB and improve management of the conjunctive use of surface-water and groundwater resources. Information produced for the URGB FAS will provide support for ongoing activities in the Rio Grande Basin including updates to the New Mexico State Water Plan and selected regional water plans; revision of the Espanola Basin model to simulate current management scenarios; updates to the Rio Grande Transboundary Integrated Hydrologic Model for the Rincon, Mesilla, and Conejos Medanos Basins; and contributions to the long-term data analysis and monitoring program activities under the U.S. Army Corps of Engineers Rio Grande Ecosystem Restoration Program (U.S. Army Corps of Engineers, 2021a). This study will benefit ongoing watershedscale modeling efforts, including the conceptual understanding of groundwater/surface-water exchange incorporated into the Upper Rio Grande Water Operations Model, which is a major cooperative effort of the USGS, Bureau of Reclamation (Reclamation), and U.S. Army Corps of Engineers. The study will also benefit the conceptual understanding of the calibration of the Rio Grande Basin (Region 13) of the USGS National Hydrologic Model (National Hydrologic Model Infrastructure [https:/www.usgs.gov/mission-areas/ water-resources/science/national-hydrologic-model-infrastructure? qt-science_center_objects=0\#qt-science_center_objects]).

\section{Study Area}

The Rio Grande flows approximately 670 miles (mi) from the headwaters in the San Juan Mountains of south-central Colorado to Fort Quitman, Texas, draining the URGB study area of 32,000 square miles (mi²) (fig. 1) that includes parts of Colorado, New Mexico, and Texas. The HUC-8s 13030102 and 13040100 extend into Mexico (fig. 1), where the Rio Grande forms the international boundary between Texas and the State of Chihuahua, Mexico. Based on acreage, the area of the URGB that lies within political boundaries is $16,70,4$, and 10 percent for Colorado, New Mexico, Texas, and Chihuahua, Mexico, respectively. The URGB, primarily located in the Southern Rocky Mountains and Basin and Range physiographic provinces, has elevations that range from 14,345 feet (ft) above North America Vertical Datum of 1988 (NAVD 88) on Blanca Peak within the Sangre de Cristo Mountains to 3,458 ft in Fort Quitman, Texas. Tributaries to the Rio Grande in the study area are the Alamosa and Conejos Rivers in Colorado, and the Rio Chama, Rio Puerco, and Jemez River in New Mexico.

Climate varies across the URGB study area but is generally arid to semi-arid with temperatures in the headwaters (Creede, Colo.) ranging from a mean high monthly temperature of 25 degrees Celsius $\left({ }^{\circ} \mathrm{C}\right)\left(77\right.$ degrees Fahrenheit $\left.\left[{ }^{\circ} \mathrm{F}\right]\right)$ in July to a mean monthly low of $-20^{\circ} \mathrm{C}\left(-4.0^{\circ} \mathrm{F}\right)$ in January (The Weather Channel, 2020). Temperatures in the lower part of the basin (Fort Quitman, Tex.) range from a mean monthly high of $34^{\circ} \mathrm{C}\left(93.2^{\circ} \mathrm{F}\right)$ in July to a mean monthly low of $2.15^{\circ} \mathrm{C}\left(35.8^{\circ} \mathrm{F}\right)$ in January (World Weather Online, 2020). The headwater areas in the San Juan and Sangre de Cristo Mountains received a mean of 40 inches (in.) of precipitation a year, mostly as snow. In summer, streamflows are supplemented by thunderstorms that are components of the North American Monsoon (Llewellyn and Vaddey, 2013). Annual mean precipitation data by HUC-8 for the years from 1985 to 2015 show that less precipitation fell in the HUC-8s 13020101-13040100 in 1995 and 2000 than in other years (table 1). Annual mean precipitation in the headwaters HUC-8 13010001 has also decreased from 38.31 in. (1985) to $29.76 \mathrm{in.}$ (2015). For the seven years of compilation data, the mean annual precipitation across the URGB study area basin was $15.90 \mathrm{in}$.

The San Luis Valley in Colorado (fig. 1), near the headwaters of the Rio Grande, is surrounded by the San Juan and La Garita Mountains to the west and the Sangre de Cristo Mountains to the east. This valley has been used as a hunting area by humans for over 12 thousand years, including a number of Paleoindians and Native Peoples (Utes, Apache, Comanche, Navajo, Arapahoe, Cheyenne, and Native Peoples from Pueblos in New Mexico), with numerous campsites in areas where bison remains can be found. Faunal assemblages in the valley indicate periods of substantial variations in the amount of moisture and climate changes (Van Ness, 2012). The Spanish arrived in the valley in the late 1500 s, where Mexico established land grants in an attempt to encourage people to settle in the valley. The first permanent settlement was established at San Luis de la Culebra in 1851. The People's Ditch, the oldest water right in Colorado, was founded in 1852 and has been used continuously for irrigation of about 2,100 acres of hay, alfalfa, and corn since its completion (Franceschini and Tucker, 2010). South from the San Luis Valley and still within the URGB, several Pueblos were established about 600 years ago. By A.D. 1300, the river valleys in New Mexico were supporting large Pueblo communities that depended on agriculture (often irrigated) to maintain the growing populations (National Park Service, 2018). As of 2020, there are 18 Pueblos within the URGB FAS (Indian Pueblo Cultural Center, 2020). The Rio Grande continues to serve as the primary source of irrigation water for agriculture throughout the basin and supports environmental and recreational uses in Colorado, New Mexico, and Texas, as well as in Mexico (Llewellyn and Vaddey, 2013).

The main stem of the Rio Grande has numerous diversions, dams, and three reservoirs. The most upstream of the dams and reservoirs is the Rio Grande Dam (fig. 1) and reservoir (not shown) near Creede, Colo. Built by the San Luis Valley Irrigation district, this reservoir stores water for agricultural use in the valley (Deere and Ault Consultants, Inc., 2018). Other dams on the river built for irrigation as part of the Middle Rio Grande Project include Cochiti Dam (fig. 1) and the Angostura, Isleta, and San Acacia diversion dams (not shown). The diversion dams are operated by the Middle Rio Grande Conservancy District (Reclamation, 2018b), whereas Cochiti Dam is operated and maintained by the U.S. Army Corps of Engineers (U.S. Army Corps of Engineers, 2021b). 


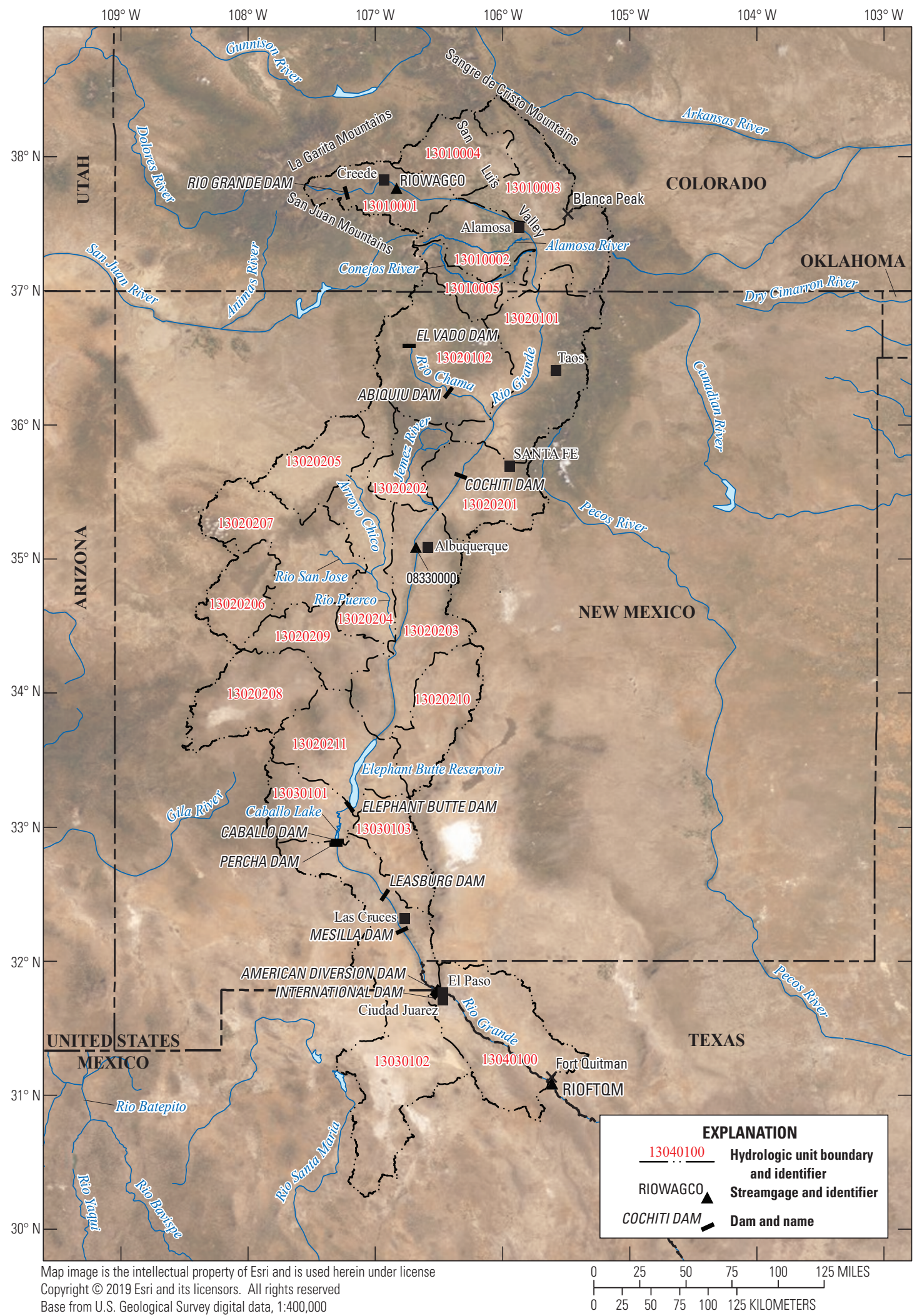

Base from U.S. Geological Survey digital data, 1:400,000

Geographic projection, North American Datum of 1983

Figure 1. Location of the Upper Rio Grande Basin study area. 
Table 1. Annual mean precipitation for the eight-digit hydrologic unit code subbasins in the Rio Grande Basin study area, 1985-2015.

[Hydrologic unit codes included in the Upper Rio Grande Basin study are shown in figure 1. Data averaged from PRISM Climate Group (2017). HUC-8, eightdigit hydrologic unit code]

\begin{tabular}{lccccccc}
\hline \multirow{2}{*}{ HUC-8 } & \multicolumn{7}{c}{ Annual mean precipitation, in inches } \\
\cline { 2 - 7 } & $\mathbf{1 9 8 5}$ & $\mathbf{1 9 9 0}$ & $\mathbf{1 9 9 5}$ & $\mathbf{2 0 0 0}$ & $\mathbf{2 0 0 5}$ & $\mathbf{2 0 1 0}$ & $\mathbf{2 0 1 5}$ \\
\hline 13010001 & 38.31 & 35.93 & 29.78 & 28.65 & 28.50 & 28.92 & 29.76 \\
13010002 & 19.02 & 20.34 & 16.39 & 13.76 & 14.93 & 12.81 & 17.71 \\
13010003 & 16.03 & 18.78 & 15.35 & 12.61 & 12.27 & 10.71 & 16.74 \\
13010004 & 20.16 & 21.16 & 18.64 & 16.20 & 15.48 & 12.89 & 17.91 \\
13010005 & 38.91 & 35.53 & 30.94 & 24.60 & 28.91 & 26.24 & 30.01 \\
13020101 & 22.64 & 23.00 & 18.51 & 16.16 & 19.59 & 17.44 & 22.77 \\
13020102 & 25.48 & 24.72 & 19.78 & 15.74 & 20.47 & 18.92 & 23.49 \\
13020201 & 19.60 & 17.58 & 11.24 & 13.87 & 15.05 & 15.76 & 18.22 \\
13020202 & 23.39 & 23.36 & 16.36 & 16.39 & 16.96 & 18.42 & 22.40 \\
13020203 & 14.56 & 13.64 & 7.64 & 12.28 & 12.94 & 11.55 & 15.36 \\
13020204 & 14.49 & 15.17 & 8.28 & 11.32 & 12.44 & 11.93 & 16.20 \\
13020205 & 12.53 & 14.32 & 9.08 & 9.76 & 10.47 & 12.62 & 15.81 \\
13020206 & 14.02 & 15.31 & 9.52 & 11.27 & 12.09 & 13.54 & 15.32 \\
13020207 & 14.67 & 15.75 & 9.33 & 12.10 & 12.21 & 14.10 & 16.13 \\
13020208 & 17.56 & 16.19 & 10.73 & 13.55 & 13.36 & 13.48 & 16.81 \\
13020209 & 13.87 & 14.75 & 7.67 & 11.60 & 12.45 & 11.82 & 14.79 \\
13020210 & 14.34 & 13.00 & 7.53 & 12.29 & 13.53 & 11.87 & 15.83 \\
13020211 & 14.79 & 13.61 & 7.96 & 12.22 & 11.60 & 11.44 & 13.11 \\
13030101 & 16.19 & 16.79 & 9.16 & 13.89 & 11.56 & 13.85 & 14.70 \\
13030102 & 13.25 & 12.96 & 7.05 & 10.64 & 9.74 & 11.58 & 13.57 \\
13030103 & 13.83 & 13.82 & 7.82 & 10.70 & 9.72 & 10.25 & 15.06 \\
13040100 & 9.95 & 12.37 & 6.84 & 7.23 & 12.02 & 9.91 & 12.74 \\
\hline
\end{tabular}

The Elephant Butte and Caballo Dams were built as part of the Rio Grande Project, to provide recreation, flood control, and hydropower. These impoundments create Elephant Butte Reservoir and Caballo Lake (Reclamation, 2018a) and provide irrigation water to south-central New Mexico and west Texas. As part of the Rio Grande Project, several diversion dams were constructed, primarily for moving water for irrigation, including Leasburg, Percha, and Mesilla (operated by the Elephant Butte Irrigation District in New Mexico), and American (operated by El Paso County Water Improvement District No. 1 in Texas).

Annual mean streamflow is tabulated for three streamgages in the URGB study area; one gage is located in the headwaters of the basin, in the central basin, and at the most downstream part of the basin at Fort Quitman, Texas (table 2). The annual mean streamflow (including base flow and releases from reservoirs) was highest in 1985 for the headwaters site at Wagon Wheel Gap (837 cubic feet per second $\left[\mathrm{ft}^{3} / \mathrm{s}\right]$ ) and the central site in Albuquerque, New Mexico $(2,269 \mathrm{ft} 3 / \mathrm{s})$. In 2005 , the most downstream streamgage in the study basin at Fort Quitman had the lowest streamflow of all the years, $153 \mathrm{ft} 3 / \mathrm{s}$. The lowest reported annual mean streamflow at the other streamgages occurred in 2010 for the headwaters site at Wagon Wheel Gap $\left(473 \mathrm{ft}^{3} / \mathrm{s}\right)$ and in 1990 for the site in Albuquerque (695 ft $3 / \mathrm{s})$ (table 2).

The Rio Grande within the URGB study area provides water to an estimated 1.4 million people for municipal use in the municipalities along the river corridor, including the cities of Santa Fe and Albuquerque, New Mexico, and El Paso, Texas. For other major cities in the study basin such as Las Cruces, New Mexico, and Ciudad Juarez, Mexico, groundwater is the primary source of municipal drinking water. Water from the Rio Grande irrigates nearly 750,000 acres in the study area, which includes estimated irrigated acres in Mexico and provides water for 18 Pueblos, 3 National Wildlife Refuges, and 1 National Monument. The largest metropolitan areas in the URGB include Albuquerque and Las Cruces, New Mexico, El Paso, Texas, and Ciudad Juarez, Mexico (fig. 1). These metropolitan areas have a current (2015) combined population of over 3.3 million people (U.S. Census Bureau, 2018; World Population Review, 2018). 
Table 2. Annual mean streamflow in the upper, middle, and lower Upper Rio Grande Basin study area, 1985-2015.

[NA, not available]

\begin{tabular}{lccc}
\hline \multirow{2}{*}{ Compilation year } & \multicolumn{3}{c}{ Annual mean streamflow, in cubic feet per second } \\
\cline { 2 - 4 } & $\begin{array}{c}\text { Rio Grande at Wagon Wheel Gap, } \\
\text { Colorado (RIOWAGC) }\end{array}$ & $\begin{array}{c}\text { Rio Grande at Albuquerque, } \\
\text { New Mexico (08330000) }\end{array}$ & $\begin{array}{c}\text { Rio Grande at Fort Quitman, Texas near Colonia } \\
\text { Luis Leon Chihuahua, Mexico (RIOFTQM) }\end{array}$ \\
\hline 1985 & 837 & 2,269 & 170 \\
1990 & 522 & 695 & 265 \\
1995 & 744 & 2,182 & 566 \\
2000 & 750 & 723 & 192 \\
2005 & 704 & 1,600 & 153 \\
2010 & 473 & 1,049 & 171 \\
2015 & 649 & 933 & NA \\
\hline
\end{tabular}

${ }^{1}$ Colorado Division of Water Resources (2018).

${ }^{2}$ U.S. Geological Survey (2018).

3International Boundary and Water Commission (2018).

\section{Methods}

Since 1950, the USGS has published water-use data in Estimated Use of Water in the United States reports (referred to as "national compilations"); the latest data are for 2015 (Dieter and others, 2018). The national compilations contain spatially varying aggregated data using information collected by numerous private, local, State, and Federal entities. Standard methods and techniques to compile, aggregate, and estimate these data have been in use since about 1995 and are outlined in the technical guidelines manual (Bradley, 2017). Both reported and estimated withdrawal data are used to aggregate water use by category for various spatial areas in the United States, including county, State, HUC-4 (1950-80), and HUC-8 (1985-95). National compilations of water use by HUC-8 have not been produced after 1995. An online matrix illustrates the changes to categories of water use as part of the 5-year national compilations (https://water.usgs.gov/ watuse/WU-Category-Changes.html).

This project used the same methods and data sources as the national compilations to compile data by HUC- 8 for all categories that were last reported in the 1995 national compilation (Solley and others, 1998). These methods include apportioning compilation county-level data to HUC-8 through statistical area weighting (HUC-8 portions in counties) and splitting countylevel withdrawals based on HUC-8 population. Metadata for the withdrawals - but not for the methods used to estimate withdrawals - in the single HUC-8 in Texas are documented in Sargent and others (2020).

Data for this study include 2015 estimates for irrigation consumptive use. After 1995, national compilations of consumptive use estimates for domestic, commercial, industrial, irrigation, and thermoelectric power were not produced. However, this report includes estimates of consumptive use for the irrigation category using data developed through the NWC and FAS efforts. The final dataset used and analyzed in this report can be found as a data release (Ivahnenko and Galanter, 2021).

\section{Sources of Data}

The primary sources of water-use data for each of the three categories are Federal and State agencies. The primary State agencies included water resources departments, engineer offices, water permitting offices, and health departments. Additional sources from entities include agricultural statistics offices, conservation boards, corporate or development commissions, water authorities, cities and local entities, and facility records. The approach for compiling and analyzing data can vary by State based on the water-use programs in each State or the availability of other reliable water-use data from the local agencies and entities.

\section{Public Supply}

Public-supply data were compiled from the previously mentioned State agencies, cities, local entities, and facility records, which showed reported annual withdrawals by source and total population served. These data were aggregated to the reporting areas (county and HUC-8). Deliveries to domestic users were determined using customer-base information or other ancillary or reported information. Domestic deliveries are used to compute per-capita use coefficients for each year of compilation, and these coefficients are then applied to the self-supplied population for estimating self-supplied domestic withdrawals. Per-capita use coefficients are computed by dividing the volume of water that is withdrawn or delivered by the number of people who use the water and are expressed as gallons per-capita daily (gpcd). All public-supply withdrawals were considered to be from freshwater sources, unless otherwise reported. 


\section{Self-Supply Domestic}

Self-supply domestic populations (mostly rural populations) were computed as the difference between the county or HUC-8 total population and the public-supply population that was served within the same geographic area. Self-supply domestic withdrawals were computed using the self-supply domestic population and per-capita use coefficients derived from the public-supply deliveries to domestic users. All selfsupply domestic withdrawals were made from fresh groundwater sources in the study area.

\section{Irrigation}

Irrigation estimates included data from State and Federal agencies, specifically Reclamation, U.S. Department of Agriculture (USDA) Census of Agriculture, and Farm Services Agency, as well as universities, irrigation districts, conservancy districts, and extension agencies. The Golf Course Superintendent's Association of America provided the irrigated acres for golf courses. Irrigation withdrawals were reported separately for golf courses and crops for Colorado and New Mexico. Texas reported irrigation withdrawals as a total amount combining both. For this report, crop and golf irrigation are reported as total irrigation. Irrigated acres for crops were reported for Colorado, New Mexico, and Texas by the Colorado Division of Water Resources, the New Mexico Office of the State Engineer, and the Farm Service Agency, respectively.

Withdrawal data were a mix of reported measurements and estimates for irrigation. Estimates were derived from the OBC (Blaney and Criddle, 1950) and MBC (USDA, 1970) methods, and produced irrigation water requirements were derived from irrigated acres, climate data, and irrigation system efficiencies. The Food and Agricultural Organization of the United Nations (1986) describes the MBC method as a theoretical approach for reference ET (ETo) estimation that is used when field-measured observations are not available. Using crop coefficients in the calculation, the method quantifies irrigation water requirements under the assumption that these crops are grown under optimal conditions, free of diseases, and with favorable soil, fertilizer, and water conditions. These conditions allow crops to reach their full production potential but are not representative of actual growing conditions where disease, drought, and poor soil conditions affect crop productivity. Total water withdrawals (as derived from both Blaney-Criddle methods) are derived from the irrigation water requirements that are supplemented with system conveyance losses.

Irrigation consumptive use, which is a fraction of the total water withdrawals, was derived either using the MBC method or from the ETa, which represents the actual growing conditions and was computed from satellite thermal-band data and the SSEBop model (Senay and others, 2013, 2016; Singh and others, 2014). The ETa is considered a surrogate value for irrigation consumptive use (Savoca and others, 2013, Maupin and others, 2012), and more realistically reflects the actual growing conditions in the field. MBC was not computed in all States in the study basin, but monthly ETa data were produced for the entire URGB, and annual totals were summarized from this source using several digital data sources to filter out and select only irrigated lands. Digital data used to filter out 2015 irrigated lands included data from the Colorado Decision Support System (Colorado) and a feature class of irrigated acres in New Mexico, Texas, and Mexico digitized for the URGB FAS (Pedraza and others, 2019). The ETa values, originally expressed as a depth of water (in millimeters) within the filtered spatial area of irrigated lands (in thousand acres), were converted to a volume (acre-foot).

\section{Estimating Irrigated Acres}

Pedraza and others (2019) created a 2015 polygon feature class of irrigated acres in New Mexico, Texas, and Chihuahua, Mexico for the URGB. The polygons representing irrigated fields were based on 1-meter (m) 2015 National Agriculture Imagery Program (NAIP) imagery (or 1-m 2014 NAIP imagery where 2015 imagery was not available) (USDA, 2017) and were developed using geoprocessing tools in Esri's ArcGIS 10.5 software suite. The Cropland Data Layer was used to assign an initial crop type to each field/polygon, and if a crop type was not available from the Cropland Data Layer, a crop was manually assigned. Techniques for the manual assignment of crop type include examining the texture, color, and (or) pattern of a crop in the NAIP imagery. Sometimes the harvesting methods were useful to determine what crop was growing; for example, alfalfa is cut several times during the growing season, and fields will often exhibit patterns of partial harvests. Where available, ground-level views (photographs) for the 2015 growing season in Google Maps and Google Earth's Street View were also used in assigning a field's crop type.

Irrigation system types were also manually assigned by using available aerial imagery collected during 2015. For the area in and around the city of El Paso, system types were assigned using a waterways shapefile (City of El Paso, 2005). The waterways shapefile consisted of canal systems and was used to intersect with field polygons. Additional field-image inspection and verification were made to assign irrigation system type and included using Google Maps and Google Earth's Street View to determine whether the field irrigation system was flood, sprinkler, or microirrigation. The final irrigated acres dataset for New Mexico, Texas, and Mexico used in this report is available in a USGS data release (Pedraza and others, 2019). Irrigated acres for the Colorado part of the URGB were provided by the Colorado Division of Water Resources Decision Support System (Colorado Decision Support System, 2016). The irrigated acres feature class was only used in the analysis of ET. 


\section{Estimating Evapotranspiration}

Evapotranspiration is the combination of water evaporation from surfaces (soils, leaves, open water) and transpiration through plants. The two separate evaporative processes typically are combined in the single term, abbreviated "ET," because both processes contribute to evaporative losses from most vegetative land surfaces and because it is difficult to measure the two processes independently. A number of methods can be used to estimate ET or potential ET at a variety of temporal and spatial scales. Two of these methods have been applied and compared in the URGB: the SSEBop method (Senay and others, 2013) and the OBC method (Blaney and Criddle, 1950). For the purposes of this report, ET is considered equal to consumptive use for irrigation.

\section{SSEBop Method}

The SSEBop model (Senay and others, 2013; 2016) was used to estimate ETa in the URGB. The SSEBop model uses spatially variable, remotely sensed, thermal land-surface data to adjust temporally variable reference ETo values to derive spatiotemporally variable estimates of ETa across a target area. Data used to parameterize the SSEBop model are summarized in table 3. Parameterization is described in Senay and others (2019) for the URGB and closely followed the methods described in Senay and others (2016) for application of SSEBop to the Colorado River Basin.

\section{Blaney-Criddle Method}

Crop consumptive use in Colorado is calculated through a FORTRAN-based computer program called StateCU (Colorado Decision Support System, 2019). This model uses the MBC (USDA, 1970), the OBC (Blaney and Criddle, 1950), and the Pochop (for bluegrass only) (Pochop and others, 1984) methods for monthly estimates and the American Society of Civil Engineers Standardized Penman-Monteith method (Jensen and others, 1990) for estimates on a daily basis. The StateCU model allows for a user to create scenarios based on select diversion structures, climate stations, drainage basins, or counties. Input information includes crop coefficients, crops by acreage, and climate stations. For the county and HUC-8 in the URGB in Colorado, the set of crop coefficients calibrated for the Rio Grande basin (CCRG) (Colorado Decision Support System, 2019) were used in estimating consumptive use for the years 2000 and 2010. In 2015, consumptive use in Colorado was estimated using MODIS satellite data (Senay and others, 2013).

The New Mexico Office of the State Engineer uses both the $\mathrm{OBC}$ and the $\mathrm{MBC}$ methods to estimate irrigation water use (Magnuson and others, 2019). Within the URGB, the OBC method was used (Magnuson and others, 2019); therefore, the OBC method will be the focus of this analysis. The OBC method estimates the total monthly consumptive use of water for a specific crop that has been ideally irrigated, as computed in the following equation (Magnuson and others, 2019):

$$
u_{m}=[(t)(p) / 100](k)
$$

$$
\begin{aligned}
& \text { where } \\
& u_{m} \text { is monthly consumptive use of water (ideal), } \\
& \text { in inches; } \\
& t \text { mean monthly air temperature, in degrees } \\
& \text { Fahrenheit; } \\
& p \quad \text { monthly percentage of annual daylight hours } \\
& \text { based on the latitude of the area of study; } \\
& \text { and } \\
& k \quad \text { seasonal consumptive use coefficient. }
\end{aligned}
$$

For each crop, there are two seasonal consumptive use coefficients $(k)$ : one for the frost-free period, and one for the frost period.

The crop irrigation coefficient (CIR) for each crop is computed by subtracting the calculated effective rainfall (Magnuson and others, 2019) from the consumptive use $\left(u_{m}\right)$ for each month. The New Mexico Office of the State Engineer then quantifies irrigation withdrawals from the CIR by accounting for the on-farm and off-farm efficiencies,

Table 3. Summary of data used to parameterize the Operational Simplified Surface Energy Balance (SSEBop) model.

[m, meter; NDVI, Normalized Difference Vegetation Index; VNIR, visible and near-infrared; GRIDMET, Gridded Surface Meteorological dataset; SRTM, Shuttle Radar Topography Mission; NA, not applicable]

\begin{tabular}{lllcl}
\hline \multicolumn{1}{c}{ Dataset } & \multicolumn{1}{c}{ Source } & Frequency & Resolution (m) & \multicolumn{1}{c}{ Reference } \\
\hline Land surface temperature $(T s)$ & Landsat 7 and 8 & 16-day & 100 & Irons and others (2012) \\
NDVI & Landsat 7 and 8 (VNIR) & 16-day & 30 & Irons and others (2012) \\
Reference evapotranspiration $(E T o)$ & GRIDMET & Daily & 4,000 & Abatzoglou (2013) \\
Maximum air temperature $(T a)$ & Daymet & Daily & 1,000 & Thornton and others (2014) \\
Elevation & SRTM & NA & 30 & Farr and Kobrick (2000) \\
\hline
\end{tabular}


depending on the irrigation water source. These withdrawals are then multiplied by irrigated acreage. For HUCs 13020211, 13030101, and 13030103, total withdrawals at the county level were used to estimate the consumptive water use by assuming on-farm and off-farm efficiencies based on the reported irrigation methods. For the other 14 HUCs within New Mexico, the CIR for the area was multiplied by the irrigated acreage within that HUC.

Consumptive use for 2015 in the Texas part of the URGB was estimated through system efficiencies. A percentage of the withdrawal that was applied to the crops was considered to be a reasonable estimate of consumptive use. The system efficiencies varied by county, and for El Paso and Hudspeth, the two counties in Texas in the URGB, system efficiency percentages were 85 and 76 , respectively. The same percentages were applied in the HUC-8s.

\section{Data Limitations}

Water withdrawals for public supply and irrigation include a combination of reported and estimated data. All self-supply domestic water use is estimated, and all hydroelectric flow and wastewater return is from reported data. The USGS 5-year national compilations, as well as this project, used substantial amounts of reported and measured data for population, public-supply withdrawals, irrigated acres, power generation, livestock populations, wastewater returns, and the quantities of materials mined. In many cases, the Federal and State agencies that collected these data have experienced decreases in both funding and personnel resources, thereby either decreasing or limiting the frequency and spatial extent of collected data. The extent and detail of reported data varies by State, requiring additional estimates in States with decreased resources to meet the requirements of the national compilation and other study efforts such as this study. The USGS internal documentation was compiled for each State as part of the national compilation effort in 2015 and served as the sources of data and methods used for each of the categories.

Challenges with compiling withdrawal data included unknown errors in the reported data and use of data older than the compilation timeframe. For example, crop acreage data from the USDA Census of Agriculture (USDA, 2015) are collected every 5 years, for years ending in " 2 " and "7." These are years offset from the USGS national compilation years (years ending in " 0 " and "5") and may present some factor of error due to extrapolation. The lack of site-specific data about water sources in most of the categories increased the difficulty in converting county-level data to the drainage-basin scale in the URGB; this is a common issue in Western States, where counties typically are very large and water users (people, crops, livestock, industries) may be distributed unevenly.

\section{Total Water Withdrawals, Public-Supply, Domestic, and Irrigation Water Withdrawals, Use, and Trends}

Water use, in a broad sense of the term, is depicted as withdrawals from groundwater or surface-water resources that are used away from the point of withdrawal (that is, offstream). Withdrawals may be delivered for a specific use, such as domestic deliveries from public suppliers, or consumptively used in the process, such as ET from irrigated crops. Also, water may be used for an instream purpose, such as water that passes through turbines at hydroelectric powerplants. In completing the water-use cycle, water returning to the environment is accounted for as a return flow, such as wastewater returns.

\section{Total Water Withdrawals for 2015}

Estimated total withdrawals for all the water-use categories (including hydroelectric) in 2015 in the URGB were $3,152.10 \mathrm{Mgal} / \mathrm{d}$. Surface water was the dominant source of water used in the URGB, composing about 71 percent of total withdrawals (table 4). Nearly all withdrawals were from freshwater sources; there was a small amount of saline groundwater that was used for public-supply and self-supplied industrial usage. All saline groundwater withdrawals within the URGB were reported in Texas (Ivahnenko and Galanter, 2021). The proportion of total 2015 withdrawals from the States in the URGB are 46 percent each in Colorado and New Mexico and 8 percent in Texas. Surface-water and groundwater withdrawals were highest in the New Mexico and Colorado parts of the URGB study area (table 4).

A comparison of 2015 water withdrawals for the URGB shows that irrigation - at 74 percent of the withdrawals - is the dominant water use for the categories of public supply, selfsupplied domestic, self-supplied industrial, thermoelectric, irrigation, livestock, mining, aquaculture, and hydroelectric (fig. 2). Hydroelectric power is considered a non-consumptive water use and is included in the water-use category list to complete the "energy water use" category, along with thermoelectric power. Without enough water flows, hydroelectric power cannot be generated. Other water-use categories in the URGB that make up about 1 percent or greater of the total water use by volume are public supply ( 9 percent) and selfsupplied domestic (1 percent), and aquaculture (1 percent). The diagram in figure 2 showing total use by category for the URGB in 2015 illustrates that when all withdrawals are considered, 98 percent of water use is for irrigation, public supply, and hydroelectric power generation. This report will focus on the higher volume, consumptively used categories of public supply, self-supplied domestic (to complete the domestic water use category), and irrigation. A discussion on basin population provides context for the categories of public-supply and selfsupplied domestic water use. 
Table 4. Total water withdrawals for the Upper Rio Grande Basin study area and States, by source, for the States in the Upper Rio Grande Basin study area, 2015.

[Total withdrawals may include small amounts of saline water, as groundwater. Mgal/d, million gallons per day]

\begin{tabular}{lccc}
\hline \multicolumn{1}{c}{ State $^{\mathbf{1}}$} & Groundwater, Mgal/d & Surface water, Mgal/d & Total, Mgal/d \\
\hline Colorado & 393.37 & $1,053.94$ & $1,447.31$ \\
New Mexico & 389.83 & $1,060.09$ & $1,449.92$ \\
Texas & 128.30 & 126.57 & 254.87 \\
\hline Total & 911.50 & $2,240.60$ & $3,152.10$ \\
\hline
\end{tabular}

${ }^{1}$ States included in the Upper Rio Grande Basin study area are shown in figure 1.

\section{Population}

Population data are presented in this report as the number of people who lived within the basin during the reporting years. Population data are either derived from the Census Bureau or obtained from other sources such as city, county, State, or statistical data summaries. The population in the part of the basin located within the United States grew from about 1.36 to 2.26 million people between 1985 and 2015 (table 5). The total population in the United States part of the URGB increased by 67 percent between 1985 and 2015, with the largest increase occurring between 1990 and 1995 when the population increased by 13 percent (fig. 3). With Ciudad Juarez, Mexico, included, the total population of the URGB had an estimated 2.01 million people in 1985 , increasing to about 3.66 million in 2015: an increase of 82 percent (table 5).

The largest population concentrations are located in New Mexico, Texas, and Mexico. In 1985, 98 percent of the total number of people in the basin resided in these states and country, and in 2015, the percentage rose to 99 percent of the total population (fig. 3). Albuquerque, El Paso, and Ciudad Juarez are the largest cities in the basin. The population in

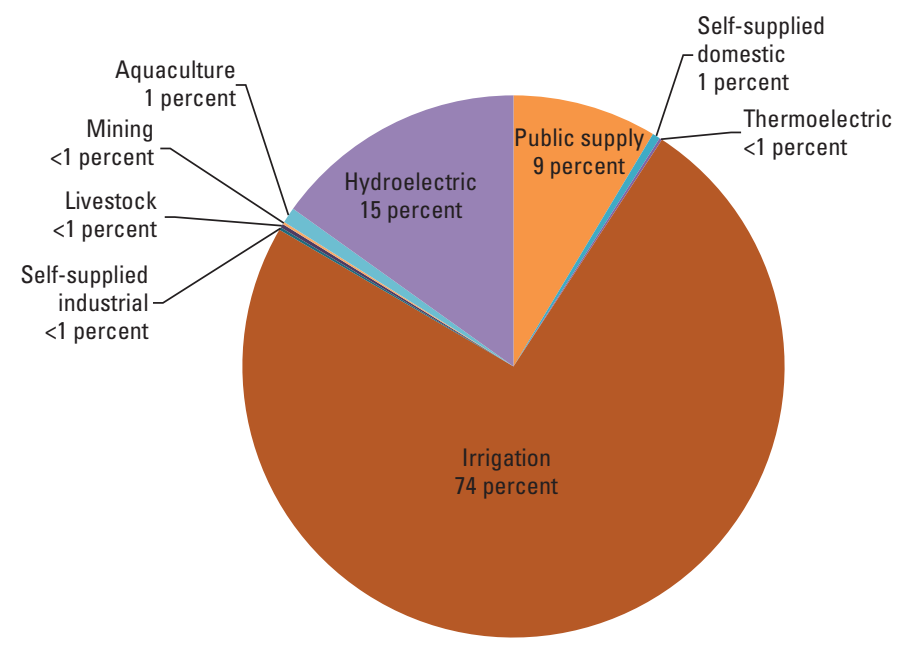

Figure 2. Total 2015 water withdrawals in the Upper Rio Grande Basin study area by water-use category. the HUC-8s within the URGB in the state of New Mexico accounted for about 60 percent of the total population of the part of the basin within the United States. With the inclusion of the population of Ciudad Juarez, Mexico, the population of the URGB in New Mexico accounted for 38 percent or more of the total basin population over the 30 years (table 5).

In 1985, the population in the Colorado part of the URGB comprised 39,640 persons. This number increased to 46,646 persons in 2015 (table 5), a change of 18 percent in the 30 -year period. The New Mexico population within the study basin has increased 62 percent from 851,220 people in 1985 to about 1.38 million in 2015. The population in Ciudad Juarez, Mexico, increased 112 percent from 1985 to 2015 . The population in Texas increased 80 percent in the years from 1985 to 2015 , having a reported population of 466,175 in 1985 and 837,487 persons (table 5) in 2015.

\section{Public Supply and Self-Supplied Domestic}

Public supply refers to water withdrawn by public and private water suppliers that provides potable water to at least 25 people or that has a minimum of 15 connections. This water may be delivered to domestic, commercial, industrial, or thermoelectric power customers, either within the drainage basin (HUC-8) where it is withdrawn or to a neighboring drainage basin. Total public-supply withdrawals include water that is eventually delivered to a customer as well as water used for public purposes (such as pools), maintenance (such as flushing lines), and losses because of leaky or broken water lines. Public-supply withdrawals may be transported across drainage basins at the HUC-8 level, creating situations where withdrawals and deliveries are reported in different drainage basins. This phenomenon creates situations in the data where large public uses and losses are calculated when in actuality the water data reflect a water conveyance to a neighboring HUC-8 and not an intrabasin transfer. Similarly, this affects other calculated values such as per-capita use rates because populations may be reported in different drainage basins than where water is withdrawn.

Total withdrawals for public supply in the URGB had a mean value of $277.32 \mathrm{Mgal} / \mathrm{d}$ from 1985 to 2015 , ranging from 231.14 Mgal/d in 1985 to $328.66 \mathrm{Mgal} / \mathrm{d}$ in 1995 
Table 5. Population in the parts of the States in the Upper Rio Grande Basin study area and Ciudad Juarez, United Mexican States, 1985-2015.

\begin{tabular}{|c|c|c|c|c|c|c|c|}
\hline \multirow{2}{*}{ State $^{1}$ or Country } & \multicolumn{7}{|c|}{ Population, in thousands } \\
\hline & 1985 & 1990 & 1995 & 2000 & 2005 & 2010 & 2015 \\
\hline Colorado & 39.640 & 40.140 & 42.750 & 46.200 & 46.420 & 46.027 & 46.646 \\
\hline New Mexico & 851.220 & 930.220 & $1,040.080$ & $1,143.200$ & $1,237.970$ & $1,344.725$ & $1,375.704$ \\
\hline Texas & 466.175 & 587.040 & 672.070 & 681.580 & 723.527 & 802.719 & 837.487 \\
\hline Ciudad Juarez, United Mexican States & 656.882 & 789.522 & 995.770 & $1,187.275$ & $1,301.452$ & $1,321.004$ & $1,398.400$ \\
\hline Total, United States & $1,357.035$ & $1,557.400$ & $1,754.900$ & $1,870.980$ & $2,007.917$ & $2,193.471$ & $2,259.837$ \\
\hline $\begin{array}{l}\text { Total, United States and Ciudad Juarez, } \\
\text { United Mexican States }\end{array}$ & $2,013.917$ & $2,346.922$ & $2,750.670$ & $3,058.255$ & $3,309.369$ & $3,514.475$ & $3,658.237$ \\
\hline
\end{tabular}

${ }^{1}$ States included in the Upper Rio Grande Basin study area are shown in figure 1.

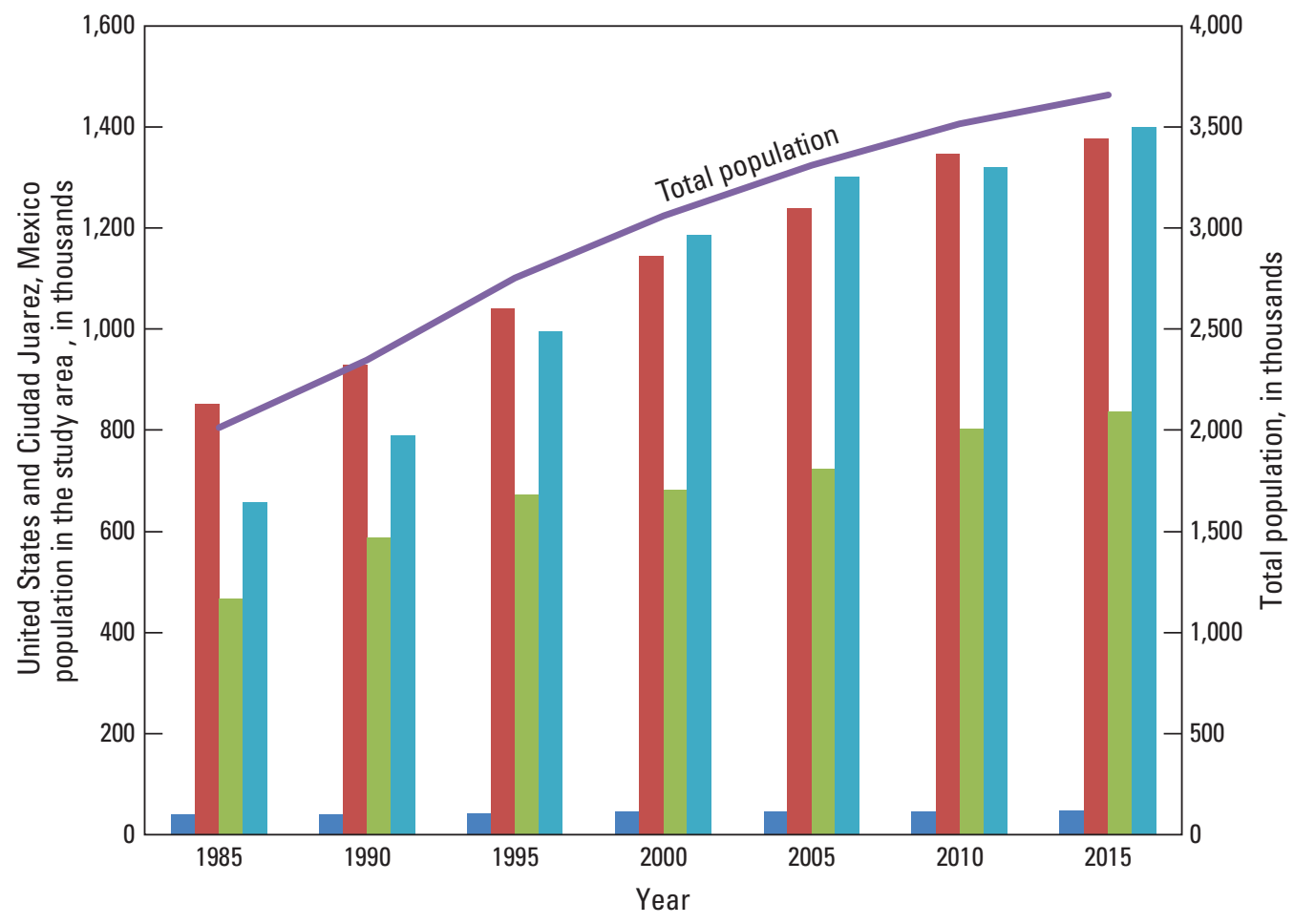

EXPLANATION

Population in the study area

Colorado

- New Mexico

- Texas

Mexico

Figure 3. Left $y$-axis shows the population of states and Ciudad Juarez, United Mexican States, located within the Upper Rio Grande Basin. Right y-axis shows the total population in the Upper Rio Grande Basin study area, 1985-2015. 
(table 6). Most of the URGB total public-supply withdrawals were in New Mexico, about 60 percent of the total, and had a mean of $170.37 \mathrm{Mgal} / \mathrm{d}$. A complete record of public-supply data from the Junta Municipal de Agua y Saneamiento for Ciudad Juarez was not available; therefore, estimates for Mexico were not included for HUCs 13030102 and 13040100. Groundwater withdrawal data from the alluvial-basin aquifer system that extends into Mexico, were reported for the years 1985,1990 , and 1995 as $58 \mathrm{Mgal} / \mathrm{d}, 80 \mathrm{Mgal} / \mathrm{d}$, and $94 \mathrm{Mgal} / \mathrm{d}$ (Heywood and Yager, 2003).

Within the URGB, groundwater is the predominant source of water for public supply (fig. 4; table 6), providing 92 and 70 percent of the total withdrawals for municipal use in 1985 and 2015, respectively. Water pumped from aquifers provided as much as 100 percent of the municipal water in Colorado for 2010, 98 percent in New Mexico for 1990, and as much as 100 percent in Texas for 2010 (table 7). In 2008, the San Juan-Chama Project was completed, allowing the City of Albuquerque to receive an allotment of Colorado River water, ending the City's sole reliance on the local aquifers (Albuquerque Bernalillo County Water Utility Authority, 2019a). The City of Albuquerque owns perpetual rights to 15 billion gallons of the San Juan-Chama Project water annually, and, in addition to maximizing the use of San Juan-Chama water, the City adopted a new water-resources strategy that included the implementation of a groundwater protection plan, conservation measures, and the use of reclaimed water for irrigation (Water Technology, 2019). Surface-water withdrawals increased in New Mexico from $4.99 \mathrm{Mgal} / \mathrm{d}$ in 2005 to $39.95 \mathrm{Mgal} / \mathrm{d}$ in 2010 and increased again in 2015 to $51.55 \mathrm{Mgal} / \mathrm{d}$ (fig. 4; table 7). These increases can be attributed to the water from the San-Juan Chama Project. As a result of the increase in surface-water withdrawals, the percentage of groundwater withdrawals in the New Mexico part of the URGB decreased to 67 percent of the total in 2015 .
The City of El Paso, the largest public water supplier in the Texas part of the URGB, relies on the Rio Grande to supplement groundwater for municipal use. Groundwater supplied between 53 and 100 percent of the withdrawals from 1985 to 2015 (table 7) in the Texas part of the URGB. Because of limited surface water and increasingly limited fresh groundwater that must be shared with Mexico, the City of El Paso, in cooperation with Fort Bliss U.S. Army post, invested in a desalination plant (El Paso Water, 2019a). Operational in 2007 as the only inland desalination plant in the United States producing drinking water, it currently (2019) can produce up to $27.5 \mathrm{Mgal} / \mathrm{d}$ of freshwater, with plans to expand the facilities to produce $42 \mathrm{Mgal} / \mathrm{d}$ to accommodate increasing population. In 2010 and 2015, 55.16 and $9.12 \mathrm{Mgal} / \mathrm{d}$, respectively, of saline groundwater for public-supply water use were reported as withdrawals in the Texas part of the URGB (table 7).

Deliveries to domestic users from public suppliers are reported for all drainage basins within the URGB and years and account for part of the total public-supply withdrawals. Deliveries for industrial, commercial, and thermoelectric data were not collected for 2000 through 2015; this incomplete dataset is not included in this report. In the URGB, domestic deliveries from public suppliers increased from 1985 to 1995 (fig. 4; table 6), but since 2005, domestic deliveries from public supply have declined. In the Colorado part of the basin, however, the estimated domestic deliveries have increased since 2000 (table 7). Domestic water is used for both indoor and outdoor purposes at residences, and this water may come from either a self-supply source (predominantly homeowner wells) or as a delivery from a public supplier. In this report, total domestic use represents the domestic deliveries from public-supply systems combined with self-supply withdrawals. Populations that are served by public suppliers are separate from self-supply populations, and the combined total of the two represent the total drainage basin population. Domestic

Table 6. Public-supply withdrawals, by source, and deliveries to domestic use, self-supply domestic withdrawals, total domestic use, and domestic per-capita use for populations served from public suppliers and self-supplied populations in the Upper Rio Grande Basin study area, 1985-2015.

[Some areas are missing; figures may not sum to totals due to independent rounding. Thous., thousand people; Mgal/d, million gallons per day; gpcd, gallons per capita daily]

\begin{tabular}{|c|c|c|c|c|c|c|c|c|c|c|c|}
\hline \multirow[b]{2}{*}{ Year } & \multicolumn{3}{|c|}{ Population (Thous.) } & \multicolumn{4}{|c|}{ Public-supply withdrawals (Mgal/d) } & \multirow{2}{*}{$\begin{array}{l}\text { Public-supply } \\
\text { domestic } \\
\text { deliveries } \\
\text { (Mgal/d) }\end{array}$} & \multirow{2}{*}{$\begin{array}{c}\text { Total } \\
\text { self-supply } \\
\text { domestic } \\
\text { withdrawals } \\
\text { (Mgal/d) }\end{array}$} & \multirow{2}{*}{$\begin{array}{c}\text { Total } \\
\text { domestic } \\
\text { withdrawals } \\
\text { and deliveries } \\
\text { (Mgal/d) }\end{array}$} & \multirow{2}{*}{$\begin{array}{c}\text { Domestic } \\
\text { per-capita } \\
\text { use } \\
\text { (gpcd) }\end{array}$} \\
\hline & $\begin{array}{l}\text { Public } \\
\text { supply }\end{array}$ & Self-supply & Total & $\begin{array}{c}\text { Groundwater, } \\
\text { fresh }\end{array}$ & $\begin{array}{l}\text { Groundwater, } \\
\text { saline }\end{array}$ & $\begin{array}{c}\text { Surface } \\
\text { water }\end{array}$ & Total & & & & \\
\hline 1985 & $1,094.357$ & 262.673 & $1,357.030$ & 213.60 & 0.00 & 17.54 & 231.14 & 168.21 & 28.83 & 197.04 & 145 \\
\hline 1990 & $1,377.300$ & 180.100 & $1,557.400$ & 259.26 & 0.00 & 18.86 & 278.12 & 183.50 & 16.92 & 200.42 & 129 \\
\hline 2000 & $1,631.811$ & 239.169 & $1,870.980$ & 242.44 & 0.00 & 60.03 & 302.47 & 190.23 & 20.02 & 210.25 & 112 \\
\hline 2005 & $1,743.582$ & 264.317 & $2,007.917$ & 246.86 & 0.00 & 29.58 & 276.44 & 210.82 & 24.01 & 234.83 & 117 \\
\hline 2010 & $1,984.970$ & 208.501 & $2,193.471$ & 150.75 & 55.16 & 39.95 & 245.86 & 175.00 & 19.86 & 194.86 & 89 \\
\hline 2015 & $2,074.458$ & 185.379 & $2,259.837$ & 184.65 & 9.12 & 84.76 & 278.53 & 160.20 & 17.29 & 177.49 & 79 \\
\hline
\end{tabular}




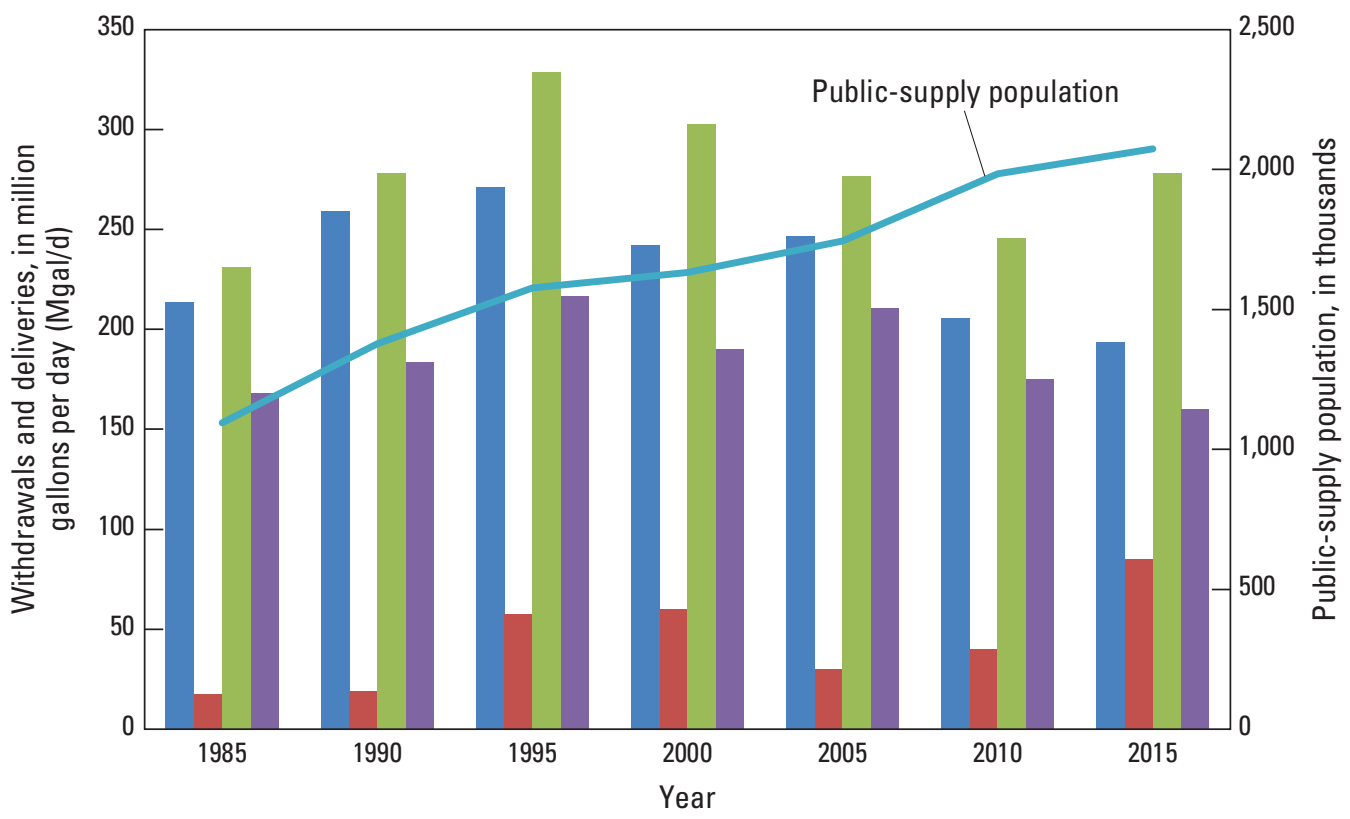

EXPLANATION

Withdrawals by source

Groundwater

Surface water

Total water withdrawals

Public-supply deliveries

Figure 4. Left y-axis shows water withdrawals by source, total water withdrawals, and public-supply deliveries. Right y-axis shows the public-supply population in the Upper Rio Grande Basin study area, 1985-2015.

per-capita use represents the mean daily per-person use in the domestic setting (homes, regardless of whether the water is delivered from a public supplier or is self-supplied) and is calculated by combining public-supply deliveries with selfsupply withdrawals averaged over the entire drainage basin population (table 6).

The total populations served by public suppliers in the URGB increased by 90 percent from 1985 to 2015 (table 6; fig. 4). Population growth accounted for the increases between the 5-year intervals in water withdrawals and domestic deliveries. In the URGB, more people were served by public-supply systems than were self-supplied. The percentage of people on public-supply systems ranged from 81 to 92 percent from 1985 to 2015 (table 6).

Most domestic water needs were met by public suppliers, accounting for more than 85 percent of total domestic use in any of the reporting years. Total domestic withdrawals in the URGB (deliveries plus self-supply withdrawals) ranged from 177.49 to $234.83 \mathrm{Mgal} / \mathrm{d}$ with the peak year in 2005 . Domestic use decreased from 2005 to 2010 by 17 percent and remained less than $200 \mathrm{Mgal} / \mathrm{d}$ in 2015. Domestic per-capita use across the entire URGB ranged from 145 gpcd in 1985 to 79 gpcd in 2015 and had a mean of 115 gpcd over the 30-year period (table 6). The per-capita daily use for the entire URGB fluctuated between the reporting years, but overall, domestic per-capita use across the basin has declined 46 percent over the 30 -year period.

Much of the decline of domestic per-capita water use in New Mexico is attributed to conservation programs for the urban areas, especially the cites of Albuquerque, Las Cruces, and Santa Fe. These cities have revised the water rate structure; provided outdoor rebates on water conservation measures, indoor appliance, and plumbing fixture rebates; and implemented a water waste reporting system in efforts to reduce water use (Hurd, 2010; Albuquerque Bernalillo County Water Utility Authority, 2019b; City of Las Cruces Water Division, 2019; Save Water Santa Fe, 2019). Similar to domestic use in New Mexico, domestic per capita decreases were reported in Texas, where domestic per capita water use declined by 45 percent from 2005 to 2015 . Much of this decrease is due to the conservation efforts by El Paso Water and the City of El Paso, including conservation ordinances, plumbing codes, rebates for both indoor appliances fixtures and outdoor landscaping (El Paso Water, 2019b), and a waste reporting system (El Paso Water, 2019c). 
On average, New Mexico accounted for about 61 percent of the total public-supply withdrawals within the URGB, followed by Texas, which had a mean of 36 percent of total withdrawals from 1985 to 2015. Combined, New Mexico and Texas had a mean of 97 percent of total public-supply withdrawals in the study area (table 7). These mean withdrawals only reflect the data for the United States part of the basin; data from Mexico would increase total withdrawals from the URGB.

\section{Irrigation}

Irrigation water use includes water that is applied by an irrigation system to sustain plant growth in all agricultural and horticultural practices. Water for irrigation can be self-supplied or delivered from irrigation or ditch companies, cooperatives, and government agencies. Reclaimed wastewater used for irrigation of crops or turf and landscaped areas - such as parks, golf courses, or cemeteries - is included in this category. Reclaimed wastewater is treated effluent that is delivered to a beneficial use (irrigation) rather than returned to the hydrologic system. All other withdrawals are considered freshwater, and irrigated acres are reported by three types of irrigation systems: sprinkler, microirrigation, and surface (surface irrigation includes flood, furrow, and gated pipe systems, hereafter collectively termed "surface").

Total irrigation withdrawals in the URGB had a mean of 2,767.66 Mgal/d from 1985 to 2015 and withdrawals peaked in 1995 (table 8; fig. 5) at 3,416.84 Mgal/d. Irrigation source water in the URGB ranged from 69 to 84 percent surface water across the 30 -year period, and the most surface water diverted in the basin for irrigation was in 1995. Groundwater withdrawals fluctuated over the 30-year period but decreased between 2005 and 2015 by 13 percent. In the Western United States, including the States in the URGB, groundwater is often used for irrigation to supplement a shortfall in surface water (Arizona Department of Water Resources, 2019). Streamflows in the URGB from 2005 to 2015 were mostly lower than in earlier years (table 2), and groundwater was used to make up the deficit to produce crops.

In the URGB, reclaimed wastewater is used to supplement irrigation for golf courses, parks, school grounds, apartment landscapes, construction, and industrial sites (El Paso Water, 2019d). Reclaimed wastewater used for irrigation in 1985 and 2015 was 0.39 and $13.30 \mathrm{Mgal} / \mathrm{d}$, respectively (table 9), and all reported use was in New Mexico and Texas. From 1985 to 2010, for the years with reported reclaimed wastewater use, the mean use was $0.23 \mathrm{Mgal} / \mathrm{d}$. The most reported reclaimed wastewater use was in 2015 (table 8).

From 1985 to 2015, slightly more than half of total irrigation withdrawals within the URGB occurred in Colorado, with a mean of 57 percent, compared to 36 percent in New Mexico and 7 percent in Texas. Total irrigation withdrawals across the Rio Grande study area peaked in 1995 and decreased by 32 percent by 2015 (fig. 5; table 9). Through a 30-year analysis of ETa in the URGB, Senay and others (2019) reported a decline in crop water use and an overall negative trend in irrigation water use. This decline became more persistent after 1995.

Irrigated lands are reported according to the type of irrigation system that is used and are classified into surface, sprinkler, or microirrigation. The number of total irrigated lands from 1985 to 2015 in the URGB had a mean of about 800 thousand acres (table 7), and most irrigated lands were consistently located in the headwaters of the URGB in the San Luis Valley, Colorado (fig. 6). Colorado had a mean of 68 percent of total irrigated lands and ranged from about 484 thousand acres (1995) to 645 thousand acres (1990) (table 9). Irrigated acres in New Mexico averaged 26 percent of the total number of irrigated acres in the basin, and the remaining 7 percent are located in Texas. Since 2000, the number of irrigated acres in the URGB has fluctuated in the 15-year period; however, overall, the number of irrigated acres has decreased by 12 percent (table 8 , fig. 5 ).

Across the 30-year period, more lands were irrigated with surface systems than other irrigation system types in the URGB. Surface irrigation increased from 62 to 88 percent of total irrigated lands and had a mean of 69 percent of the acres. Microirrigation systems compose 0.2 percent or less of the irrigated acres in the basin in New Mexico and Texas and were first reported in 1995 (table 9). From 1985 to 2015, the surface systems decreased in the basin by about 38 percent, and the number of acres of sprinkler and microirrigation systems increased.

In the 30-year period, surface irrigation has decreased, and sprinkler-irrigated acres have increased in the San Luis Valley in Colorado. Surface irrigation in the Colorado part of the URGB has decreased by 51 percent from about 480 thousand acres in 1985 to 237 thousand in 2015 (table 9). Acres in Colorado irrigated by sprinkler systems (predominately center pivot systems), have increased 179 percent from about 99 thousand acres in 1985 to about 275 thousand acres in 2015. In this dataset, the number of sprinkler acres surpassed the number of surface irrigated acres in 2000 (fig. 7A). The switch from flood irrigation to the more efficient sprinkler began in the 1970s and allowed agriculture to expand through more efficient irrigation.

However, the increase in agriculture has brought additional issues to the San Luis Valley in Colorado. The issue receiving the most attention from local water planners is the declining water level in the local aquifers because of a multi-year drought that began in 2002 and the overuse of the aquifer for irrigation. The aquifer in the San Luis Valley has had drawdown to the point where some wells have dried and streamflow in the Rio Grande has diminished (Blankenbuehler, 2016). In response to the depleted aquifer in the valley, the State of Colorado issued a statement indicating that if the aquifer did not show recovery and the water system could not reach a sustainable level by the year 2031, the State Engineer would be forced to shut off irrigation wells in the valley (Bowlin, 2019). In response to the State of Colorado's statement on irrigation wells being turned off, farmers and 
Table 7. Public-supply withdrawals, by source, deliveries to domestic use, and domestic per-capita use for populations served from public suppliers for the parts of the States in the Upper Rio Grande Basin study area, 1985-2015.

[Some areas are missing; figures may not sum to totals due to independent rounding. Thous., thousand people; Mgal/d, million gallons per day; gpcd, gallons per capita daily; - - no data entered]

\begin{tabular}{|c|c|c|c|c|c|c|c|}
\hline State $^{1}$ & 1985 & 1990 & 1995 & 2000 & 2005 & 2010 & 2015 \\
\hline \multicolumn{8}{|c|}{ Public-supply groundwater withdrawals (Mgal/d) } \\
\hline Colorado & 5.16 & 5.17 & 5.32 & 4.22 & 5.76 & 7.18 & 7.27 \\
\hline Texas $^{2}$ & 74.05 & 86.69 & 75.67 & 63.71 & 69.56 & 61.69 & 82.29 \\
\hline Total & 213.60 & 259.26 & 271.26 & 242.44 & 246.86 & 205.91 & 193.77 \\
\hline Colorado & 0.38 & 0.66 & 6.13 & 0.53 & 0.14 & 0.00 & 0.99 \\
\hline New Mexico & 4.70 & 3.20 & 5.06 & 3.79 & 4.99 & 39.95 & 51.55 \\
\hline Texas & 12.46 & 15.00 & 46.21 & 55.71 & 24.45 & 0.00 & 32.22 \\
\hline Total & 17.54 & 18.86 & 57.40 & 60.03 & 29.58 & 39.95 & 84.76 \\
\hline \multicolumn{8}{|c|}{ Public-supply total withdrawals (Mgal/d) } \\
\hline Total & 231.14 & 278.12 & 328.66 & 302.47 & 276.44 & 245.86 & 278.53 \\
\hline \multicolumn{8}{|c|}{ Domestic deliveries (Mgal/d) } \\
\hline Colorado & 4.37 & 4.82 & 4.72 & 3.82 & 4.24 & 5.03 & 5.19 \\
\hline New Mexico & 97.76 & 97.53 & 111.96 & 100.07 & 98.94 & 96.14 & 87.06 \\
\hline Texas $^{2}$ & 66.08 & 81.15 & 100.28 & 86.34 & 107.64 & 73.83 & 67.95 \\
\hline Total & 168.21 & 183.50 & 216.96 & 190.23 & 210.82 & 175.00 & 160.20 \\
\hline \multicolumn{8}{|c|}{ Public-supply population (Thous.) } \\
\hline Colorado & 24.550 & 27.540 & 29.30 & 30.600 & 28.430 & 27.027 & 29.100 \\
\hline Texas & 142 & 138 & 150 & 127 & 150 & 94 & 83 \\
\hline Total & - & - & - & - & - & - & - \\
\hline
\end{tabular}

${ }^{1}$ States included in the Upper Rio Grande Basin study area are shown in figure 1.

${ }^{2}$ Groundwater totals in Texas 2010 and 2015 include saline water. 
Table 8. Irrigation withdrawals, source water, consumptive use, and irrigated acres by system type in the Upper Rio Grande Basin study area, 1985-2015.

[Mgal/d, million gallons per day; ta, thousand acres]

\begin{tabular}{|c|c|c|c|c|c|c|c|c|c|c|}
\hline \multirow[b]{2}{*}{ Year } & \multicolumn{6}{|c|}{ Water } & \multicolumn{4}{|c|}{ Irrigated lands } \\
\hline & $\begin{array}{l}\text { Groundwater } \\
\text { (Mgal/d) }\end{array}$ & $\begin{array}{c}\text { Surface } \\
\text { water } \\
\text { (Mgal/d) }\end{array}$ & $\begin{array}{c}\text { Total } \\
\text { withdrawals } \\
\text { (Mgal/d) }\end{array}$ & $\begin{array}{c}\text { Consumptive } \\
\text { use } 1^{1} \\
\text { (Mgal/d) }\end{array}$ & $\begin{array}{c}\text { Conveyance } \\
\text { loss }^{2} \\
\text { (Mgal/d) }\end{array}$ & $\begin{array}{c}\text { Reclaimed } \\
\text { wastewater } \\
(\text { Mgal/d) }\end{array}$ & $\begin{array}{c}\text { Sprinkler } \\
\text { (ta) }\end{array}$ & $\begin{array}{c}\text { Surface } \\
\text { (ta) }\end{array}$ & $\begin{array}{l}\text { Microirrigation } \\
\text { (ta) }\end{array}$ & $\begin{array}{c}\text { Total } \\
\text { (ta) }\end{array}$ \\
\hline 1985 & 511.09 & $2,291.74$ & $2,802.83$ & $1,164.85$ & 558.99 & 0.39 & 103.89 & 732.98 & 0.00 & 836.87 \\
\hline 1990 & 835.53 & $1,947.77$ & $2,783.30$ & $1,543.48$ & 713.21 & 0.31 & 251.12 & 669.28 & 0.00 & 920.40 \\
\hline 1995 & 545.61 & $2,871.23$ & $3,416.84$ & $1,398.54$ & $1,179.82$ & 0.34 & 185.14 & 564.87 & 1.33 & 751.34 \\
\hline 2005 & 758.46 & $2,045.39$ & $2,803.85$ & 737.02 & 335.28 & 0.35 & 271.57 & 471.26 & 0.89 & 743.72 \\
\hline 2010 & 688.72 & $1,846.89$ & $2,535.61$ & $1,092.47$ & 599.16 & 0.00 & 290.94 & 469.41 & 0.80 & 761.15 \\
\hline 2015 & 656.68 & $1,675.71$ & $2,332.39$ & 806.39 & $1,093.85$ & 13.30 & 283.15 & 454.81 & 0.18 & 738.14 \\
\hline
\end{tabular}

${ }^{1}$ Consumptive use numbers are incomplete for the years 2000, 2005, and 2010.

${ }^{2}$ Conveyance loss numbers are incomplete for the years 2000, 2005, 2010, and 2015.

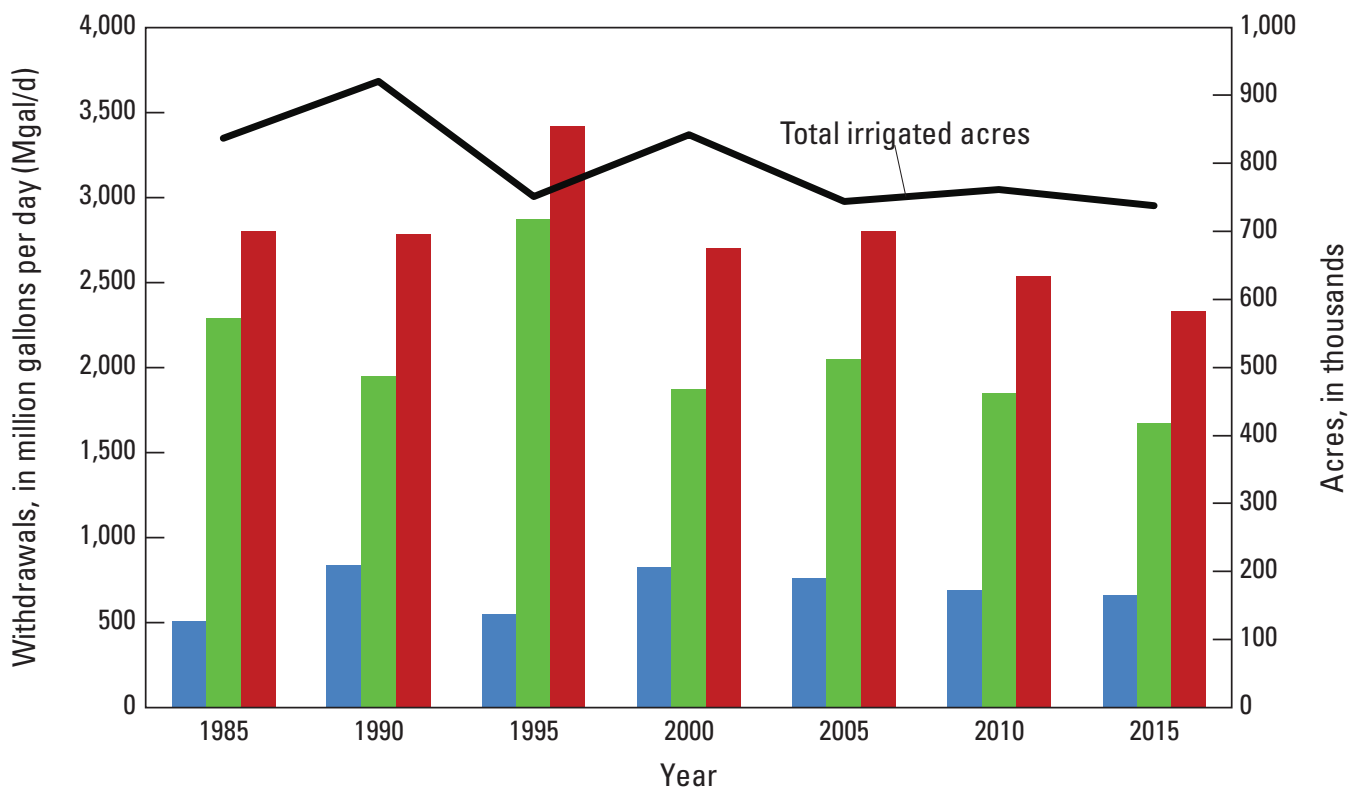

EXPLANATION

Irrigation withdrawals by source

Groundwater

Surface water

Total water withdrawals

Figure 5. Left y-axis shows irrigation withdrawals by source and total water withdrawals. Right $y$-axis shows total number of irrigated acres in the Upper Rio Grande Basin study area, 1985-2015. 
Table 9. Irrigation withdrawals, source water, consumptive use, and irrigated acres by system type for the parts of the States in the Upper Rio Grande Basin study area, 1985-2015.

[Mgal/d, million gallons per day; ta, thousand acres; NA, not available]

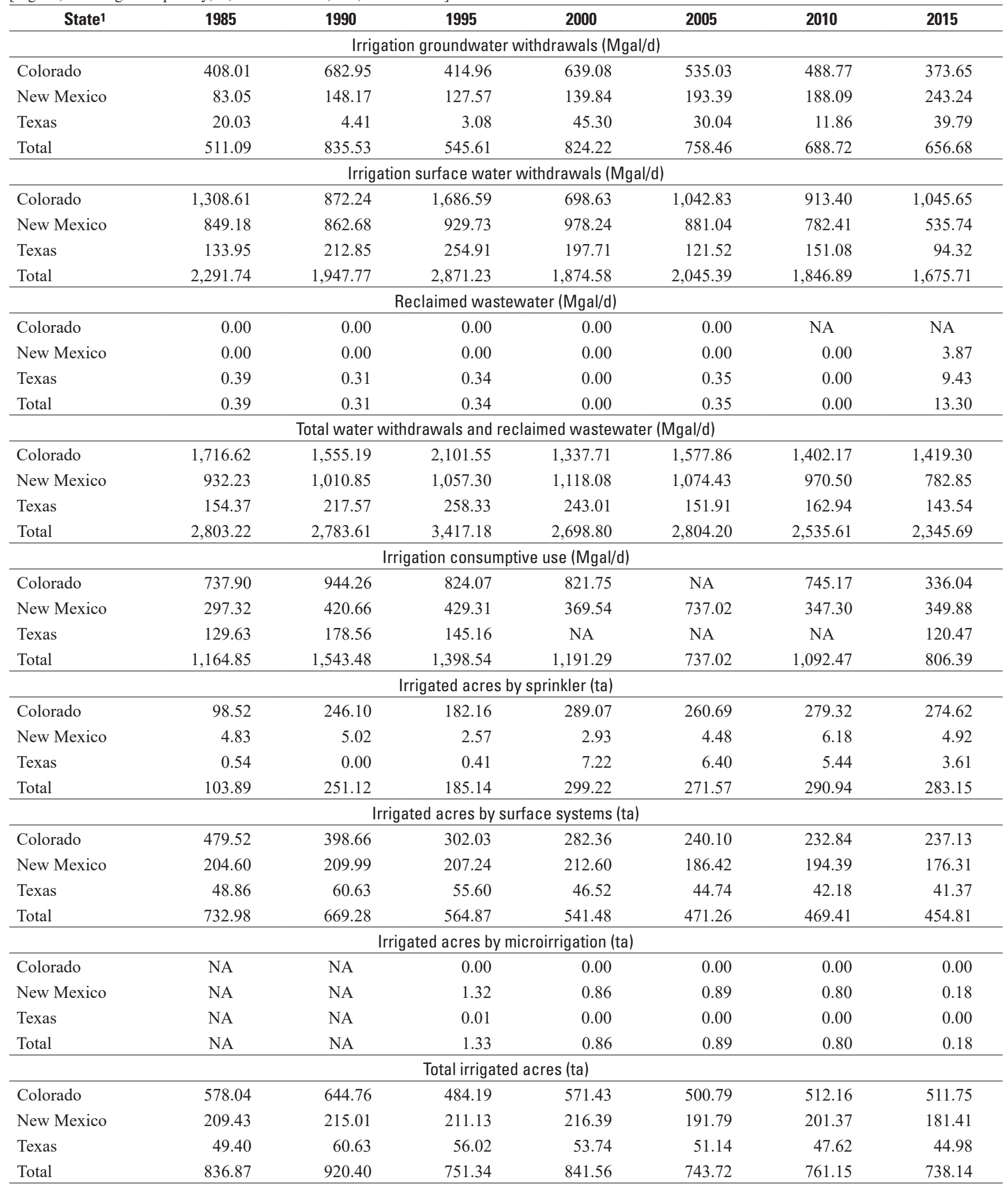

${ }^{1}$ States included in the Upper Rio Grande Basin study area are shown in figure 1. 


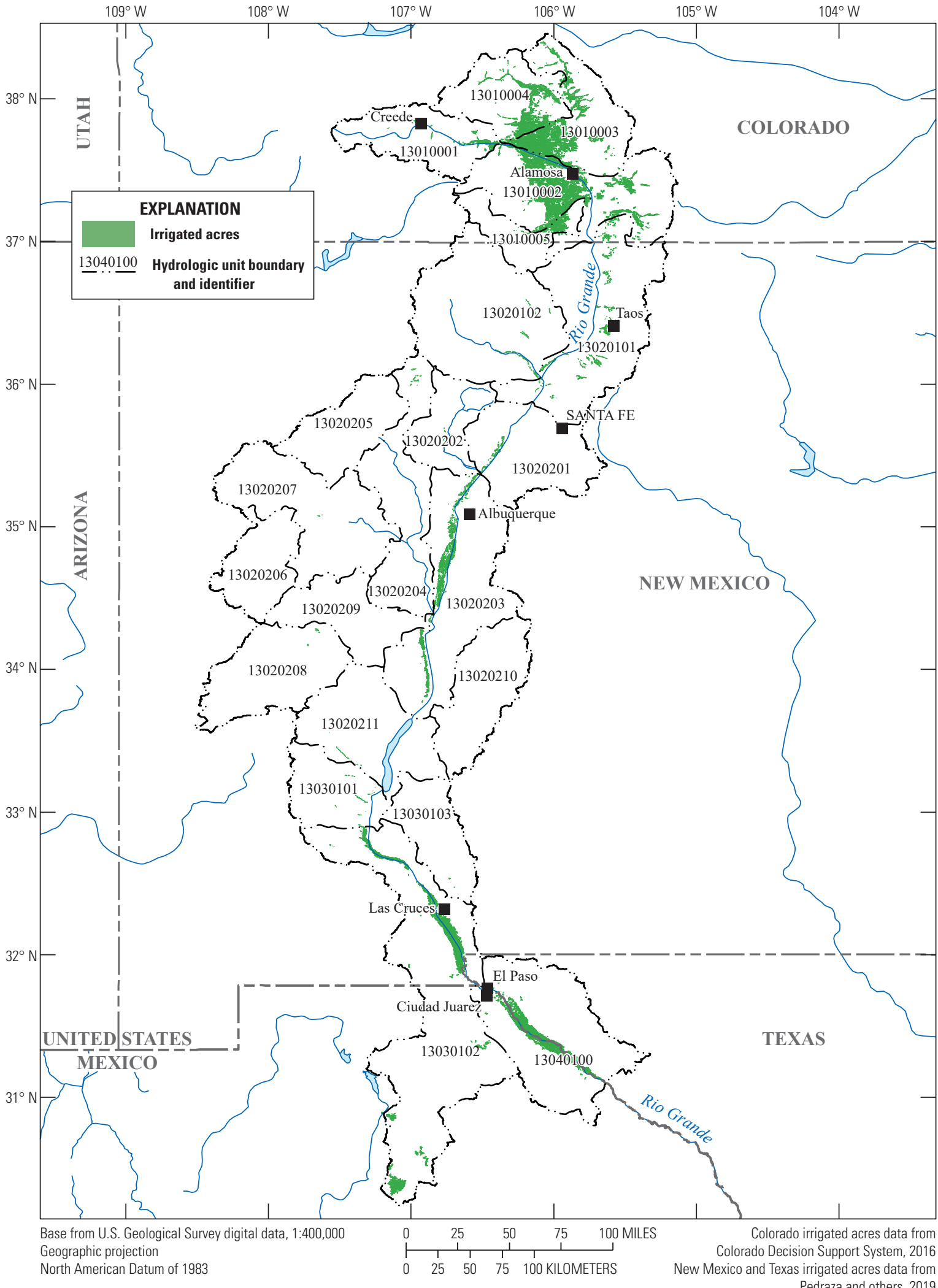

Figure 6. Irrigated acres in the Upper Rio Grande Basin study area in 2015. 

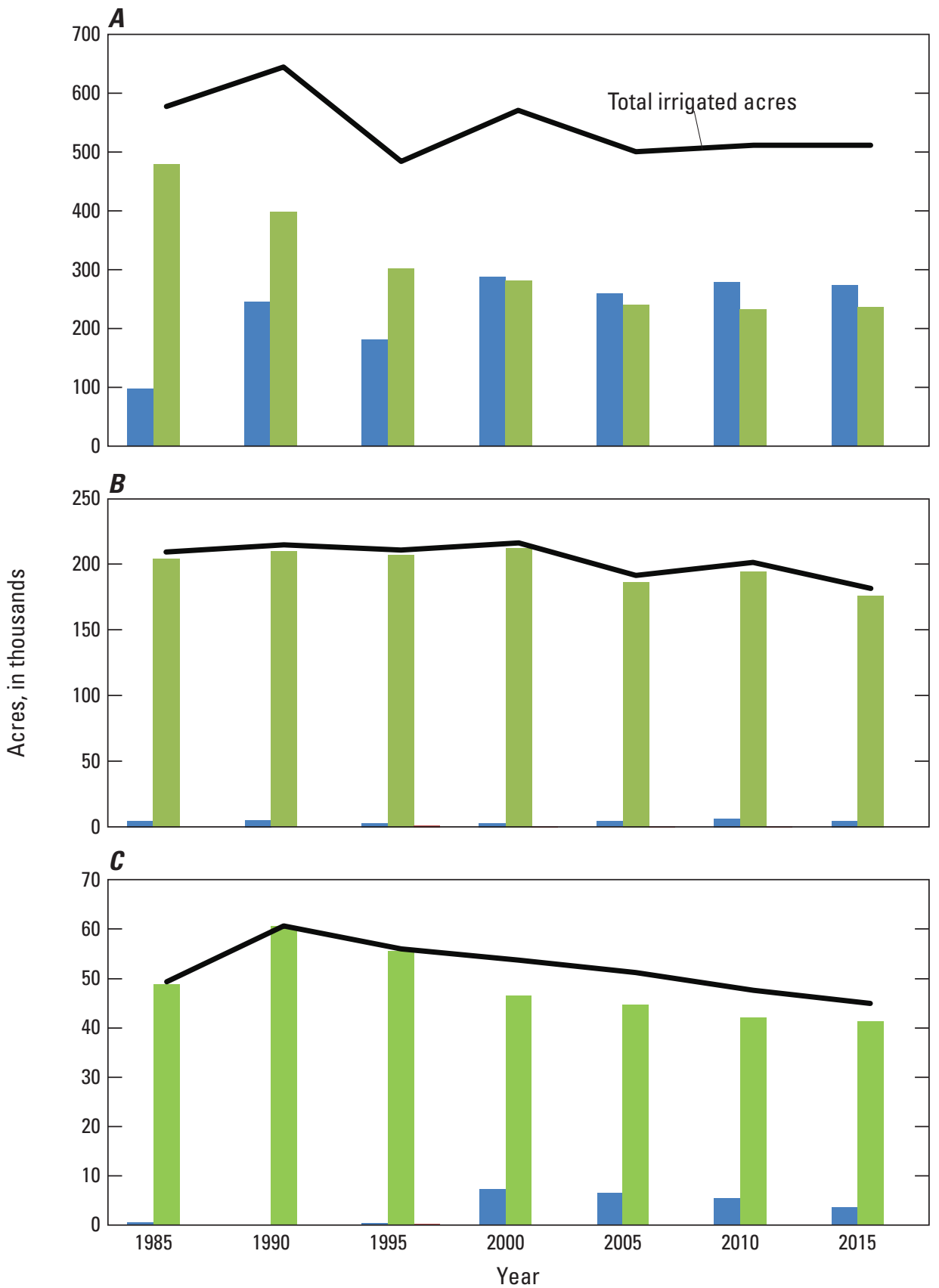

EXPLANATION

Irrigated acres by system type

Sprinkler

Surface

Microirrigation

Figure 7. Irrigated acres by system type and total irrigated acres for $A$, Colorado; $B$, New Mexico; and $C$, Texas in the Upper Rio Grande Basin study area, 1985-2015. 
ranchers in the San Luis Valley are trying an experiment in water self-governance, wherein irrigators pay other irrigators in the valley to fallow fields (Bowlin, 2019).

In the New Mexico part of the URGB, surface irrigation is reported as the dominant system type (fig. $7 B$ ). Irrigation by surface systems accounts for $97-98$ percent of the way water is provided to crops. As in New Mexico, crops in Texas (fig. 7C) are irrigated primarily by surface systems, and in 1990 , there were no other irrigation systems reported but surface. In 2015, surface irrigation provided water to crops for 92 percent of the irrigated acres in Texas.

\section{Irrigated Crop Evapotranspiration in 2015}

Consumptive use by crops (that is, ETa) is an important component of a water budget, especially in areas or drainage basins where agriculture is a dominant anthropogenic variable. As a part of the URGB FAS, Senay and others (2018) provided estimated annual crop consumptive use data as Landsat SSEBop (ETa). The estimated ETa of crops grown in the basin, an inventory of the crops, by acreage, in addition to a comparison of crop consumptive use estimating methods are presented in this section. The Landsat-based SSEBop ETa data are compared to the MODIS-based SSEBop, the widely used OBC method, and an irrigation rate method for 2015 by HUC-8 across the URGB in table 10. Senay and others (2019) describe SSEBop ETa 2015 annual data for the URGB (fig. 8) and ETa is itemized by HUC-8 and crop in table 11 .

\section{Comparison of Methods}

As the methods used to estimate water use evolve, it is beneficial to compare the results from new methods to the results of methods that are currently (2020) used. Water-use estimates from the MODIS-based SSEBop (Colorado), OBC (New Mexico), and irrigation rate (Texas) methods that were used in the 2015 water-use compilations (Dieter and others, 2018) were compared against current Landsat-based SSEBop ETa data (Senay and others, 2018). Landsat-based SSEBop ETa data (Senay and others, 2018) were extracted for areas of known irrigated agriculture and averaged within each HUC-8 for each month of the growing season. The growing season for each HUC-8 was determined using Natural Resources Conservation Service Climate Analysis for Wetlands tables (National Water and Climate Center, 2018) for climate stations within the area of the HUC-8 as guidance. PRISM monthly precipitation data (PRISM Climate Group, 2017) were averaged over each HUC-8 and converted to effective precipitation using the Reclamation method used by Blaney and Criddle (1950). The effective precipitation was subtracted from the average ETa value to estimate the water supplied from irrigation (net ET), which was then multiplied by the known irrigated area in the HUC-8. The multiplication of net ET and the known irrigated areas provided the estimate of irrigation water use by HUC- 8 .
The 2015 county consumptive water-use estimates for Colorado, New Mexico, and Texas that are explained in previous sections were used for the comparison. For Colorado, Texas, and three HUCs within New Mexico (13020211, 13030101, and 13030103), county water-use estimates were spatially redistributed to HUC-8 to be comparable with the Landsat-based SSEBop data. Although the water-use estimates for the past water-use compilations were distributed from county to HUC-8 based on area (Dieter and others, 2018), the estimates for this comparison for HUCs 13020211, 13030101, and 13030103 were distributed based on the proportion of irrigated acres to produce the most accurate comparison to data from a finer spatial resolution. This redistribution is particularly important in the arid southwest, where agriculture can be very localized and not equally distributed. Locally determined CIRs (which account for effective precipitation) were published for the other 14 HUCs containing irrigated acreage within New Mexico (Magnuson and others, 2019). For these 14 HUCs, the CIR was multiplied by the irrigated acreage within the HUC to calculate the $\mathrm{OBC}$ consumptive use (table 10). The Texas estimates were distributed based on area because of a lack of data on the irrigated acre distribution in Hudspeth County outside of the basin.

Comparing the 2015 State estimates by the various methods (OBC, MODIS-based SSEBop, or irrigation rate based on estimation) to the Landsat-based SSEBop method (table 8), consumptive use for the State estimates were overall higher than the Landsat-based SSEBop methods. The New Mexico HUC-8 estimates are based on the OBC method and tend to be higher than the Landsat-based SSEBop results (SSEBop ETa has a mean of 56 percent less than OBC ETo in HUC-8s that are located only in New Mexico; table 10). This difference is expected because the two methods represent different field conditions. The OBC method calculates an "ideal" crop irrigation requirement, whereas the SSEBop method calculates an "actual" crop water use. The SSEBop method begins by using a different method to estimate "ideal" reference ETo, but importantly attenuates this ETo based on observed thermal reflectance for small (100-m Landsat pixel) land areas (Senay and others, 2019; Senay, 2018). As a result, SSEBop actual crop water use (ETa) would be expected to be less than the ideal crop irrigation requirement because the SSEBop estimate reflects factors that attenuate ET. Factors include limitations in water available for irrigation, non-uniform water application within a field, partial canopy cover, and other spatial and temporal ET reductions from crop stress.

The HUC-8 water-use estimates in Colorado from the MODIS-based SSEBop data vary widely by HUC-8; MODIS estimates are lower than Landsat-based SSEBop data in one HUC (13010004) but higher than estimates from the Landsatbased SSEBop data in the other HUCs (by a mean of 18 percent in HUC-8s that are located only in Colorado; table 10). It is important to note that the MODIS data have a lower resolution (1 kilometer) than the Landsat data $(30 \mathrm{~m})$, and the MODISbased water-use estimates required a dryland correction factor to account for non-irrigated land in a pixel (Dieter and others, 2018). 
Table 10. Comparison of consumptive water-use estimates at an 8-digit hydrologic unit code (HUC-8) spatial resolution.

[Percent difference compares 2015 Landsat-based SSEBop to 2015 compilation method (Original Blaney-Criddle plus MODIS-based SSEBop) consumptive-use estimates. A positive percent difference represents that the compilation method estimate was greater than the Landsat-based SSEBop consumptive-use estimate. SSEBop, Operational Simplified Surface Energy Balance model; MODIS, Moderate Resolution Imaging Spectroradiomter; HUC-8, 8-digit hydrologic unit code; af, acre-feet; - , data not available]

\begin{tabular}{|c|c|c|c|c|c|c|c|}
\hline HUC-81 & State ${ }^{1}$ & $\begin{array}{c}\text { Original } \\
\text { Blaney-Criddle } \\
\text { consumptive } \\
\text { use (af) }\end{array}$ & $\begin{array}{c}\text { MODIS-based } \\
\text { SSEBop } \\
\text { consumptive } \\
\text { use (af) }\end{array}$ & $\begin{array}{l}\text { Irrigation-rate } \\
\text { based } \\
\text { estimation (af) }\end{array}$ & $\begin{array}{l}\text { Total of } 2015 \\
\text { compilation } \\
\text { methods (af) }\end{array}$ & $\begin{array}{l}\text { Landsat-based } \\
\text { SSEBop } \\
\text { consumptive } \\
\text { use (af) }\end{array}$ & $\begin{array}{c}\text { Percent } \\
\text { difference }\end{array}$ \\
\hline & & [A] & [B] & [C] & {$[\mathrm{D}=\mathrm{A}+\mathrm{B}+\mathrm{C}]$} & [E] & {$[F=(D-E) / D]$} \\
\hline 13010001 & Colo. & - & 5,758 & - & 5,758 & 3,049 & 47 \\
\hline 13010002 & Colo., N. Mex & 0 & 176,535 & - & 176,535 & 163,566 & 7 \\
\hline 13010003 & Colo. & - & 114,938 & - & 114,938 & 95,708 & 17 \\
\hline 13010004 & Colo. & - & 43,271 & - & 43,271 & 47,509 & -10 \\
\hline 13010005 & Colo., N. Mex & 2,639 & 31,734 & - & 34,373 & 17,409 & 49 \\
\hline 13020101 & Colo., N. Mex & 70,851 & 3,932 & - & 74,782 & 17,083 & 77 \\
\hline 13020102 & N. Mex & 29,525 & - & - & 29,525 & 6,129 & 79 \\
\hline 13020201 & N. Mex & 8,376 & - & - & 8,376 & 3,998 & 52 \\
\hline 13020202 & N. Mex & 1,261 & - & - & 1,261 & 542 & 57 \\
\hline 13020203 & N. Mex & 167,505 & - & - & 167,505 & 72,672 & 57 \\
\hline 13020204 & N. Mex & 3,384 & - & - & 3,384 & 1,121 & 67 \\
\hline 13020207 & N. Mex & 1,483 & - & - & 1,483 & 284 & 81 \\
\hline 13020208 & N. Mex & 2,215 & - & - & 2,215 & 178 & 92 \\
\hline 13020211 & N. Mex & 1,184 & - & - & 1,184 & 227 & 81 \\
\hline 13030101 & N. Mex & 2,300 & - & - & 2,300 & 494 & 79 \\
\hline 13030103 & N. Mex & 377 & - & - & 377 & 88 & 77 \\
\hline 13030102 & N. Mex, Tex. & 196,056 & - & 12,983 & 209,038 & 163,666 & 22 \\
\hline 13040100 & Tex. & - & - & 122,190 & 122,190 & 74,650 & 39 \\
\hline
\end{tabular}

${ }^{1}$ HUC-8 and States in the Upper Rio Grande Basin study area are shown in figure 1.

The HUC- 8 water-use estimates in Texas also are higher than the Landsat-based SSEBop results. For the one HUC-8 located solely in Texas (13040100), the SSEBop estimate is 39 percent less than irrigation-rate based estimate used by Texas (table 10). The irrigation rates used in the Texas wateruse estimates are informed by metered data where data are available, and this may be an advantage compared to other water-use estimation methods.

\section{Crop Evapotranspiration}

Crop consumptive use (or ETa) is a component in the URGB water budget. For 2015, ETa based on the SSEBop model are represented as inches in depth (converted from millimeters) by crop by HUC- 8 in table 11 . The ETa demand presented in this section of the report does not differentiate whether the water source used to meet this demand is from irrigation or rainfall. Statistics for ETa were generated as part of the ESRI GIS Zonal Statistics (ESRI, 2020) analysis package, and the minimum, maximum, and mean ETa for each identified crop in a HUC- 8 are tabulated. Numbers of irrigated acres and crops are based on data reported for 2015 for Colorado (Colorado Decision Support System, 2016) and for New Mexico, Texas, and Mexico (Pedraza and others, 2019). Variations in 2015 ETa between crops and system types are also presented (table 12).

In 2015, the five primary crops or forage grown in the URGB based on number of irrigated acres, in decreasing order of total irrigated acres, were as follows: grass pastures (grassland/pastures) (236 thousand acres), alfalfa (228 thousand acres), barley (65.5 thousand acres), cotton (61.7 thousand acres), and potatoes (54.5 thousand acres). Other important crops in the basin include pecans (41.7 thousand acres), small grains ( 7.3 thousand acres), onions (3.8 thousand acres), and vegetables (2.9 thousand acres) (table 11). In 2015, there were an estimated 1.63 thousand acres identified as chili peppers, grown in HUCs 13020203 and 13030102. HUC 13030102 is also the HUC with the most diversity of crops: a total of 24 crops, including some acreages that were double cropped, were identified in this HUC. 


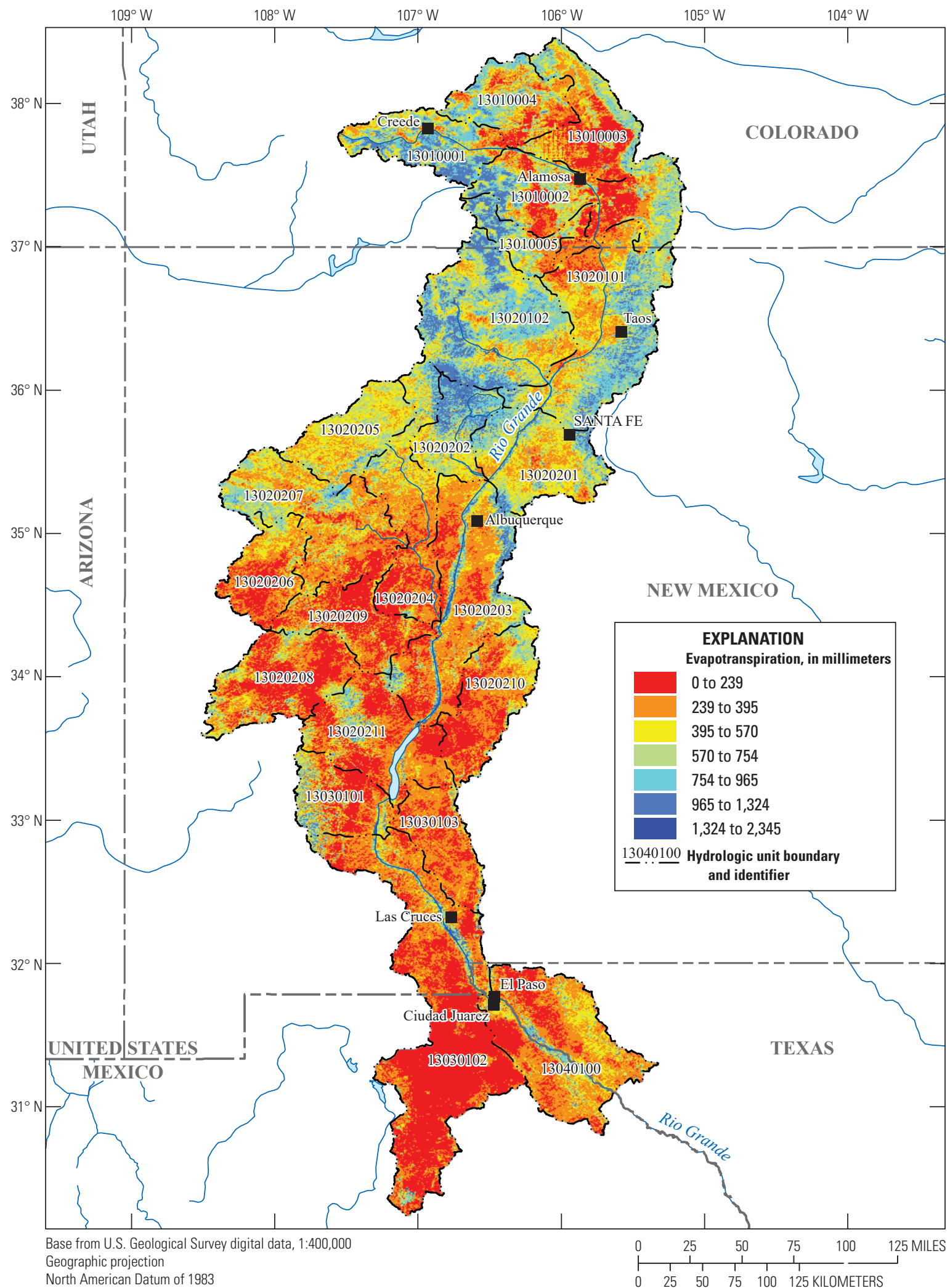

Figure 8. Operational Simplified Surface Energy Balance (SSEBop) model estimates of annual evapotranspiration in the Upper Rio Grande Basin study area, 2015. 
Table 11. Operational Simplified Surface Energy Balance (SSEBop) model estimates of actual evapotranspiration and irrigated acres by crop and 8-digit hydrologic unit code in the Upper Rio Grande Basin study area, 2015.

[HUC-8, 8-digit hydrologic unit code; ETa, actual evapotranspiration]

\begin{tabular}{|c|c|c|c|c|}
\hline Crop & $\begin{array}{c}\text { Irrigated acres, in } \\
\text { thousands }\end{array}$ & $\begin{array}{l}\text { ETa minimum, in } \\
\text { inches per year }\end{array}$ & $\begin{array}{l}\text { ETa maximum, in } \\
\text { inches per year }\end{array}$ & $\begin{array}{c}\text { ETa mean, in inches } \\
\text { per year }\end{array}$ \\
\hline \multicolumn{5}{|c|}{113010001} \\
\hline Grass pasture & 1.49 & 6.44 & 49.12 & 24.01 \\
\hline Alfalfa & 4.85 & 10.48 & 38.09 & 24.24 \\
\hline New alfalfa & 0.33 & 6.70 & 35.82 & 26.48 \\
\hline \multicolumn{5}{|c|}{113010002} \\
\hline Barley & 16.07 & 7.07 & 37.17 & 23.56 \\
\hline Cover crop & 0.39 & 10.62 & 27.16 & 18.44 \\
\hline Grass pasture & 105.01 & 3.17 & 50.06 & 21.62 \\
\hline New alfalfa & 18.38 & 5.88 & 43.43 & 23.77 \\
\hline Potatoes & 4.84 & 7.09 & 30.29 & 18.08 \\
\hline Wheat & 0.13 & 11.10 & 26.48 & 21.54 \\
\hline Wheat, spring & 0.55 & 12.31 & 30.43 & 23.21 \\
\hline \multicolumn{5}{|c|}{113010003} \\
\hline Alfalfa & 18.80 & 4.71 & 37.14 & 23.87 \\
\hline Barley & 40.72 & 4.89 & 34.23 & 20.15 \\
\hline Cover crop & 9.01 & 4.46 & 27.84 & 12.13 \\
\hline Grass pasture & 38.65 & 2.77 & 45.04 & 20.24 \\
\hline New alfalfa & 7.65 & 4.88 & 33.62 & 18.96 \\
\hline Potatoes & 45.21 & 4.54 & 29.15 & 15.70 \\
\hline \multicolumn{5}{|c|}{113010004} \\
\hline Barley & 7.96 & 7.57 & 31.28 & 21.93 \\
\hline Cover crop & 1.64 & 7.87 & 28.97 & 17.31 \\
\hline Grass pasture & 35.26 & 3.30 & 50.09 & 23.26 \\
\hline New alfalfa & 4.23 & 9.46 & 39.32 & 24.14 \\
\hline Potatoes & 4.15 & 7.69 & 25.26 & 16.95 \\
\hline Small grains & 0.58 & 9.56 & 33.94 & 23.08 \\
\hline Vegetables & 0.14 & 13.13 & 26.47 & 21.88 \\
\hline Wheat & 0.70 & 10.48 & 28.76 & 23.95 \\
\hline \multicolumn{5}{|c|}{113010005} \\
\hline Alfalfa & 6.74 & 8.56 & 40.76 & 24.30 \\
\hline Barley & 0.09 & 10.56 & 24.96 & 19.96 \\
\hline Grass pasture & 32.32 & 7.09 & 38.81 & 21.03 \\
\hline New alfalfa & 1.26 & 8.89 & 33.87 & 18.72 \\
\hline Small grains & 0.21 & 10.18 & 21.56 & 17.21 \\
\hline
\end{tabular}


Table 11. Operational Simplified Surface Energy Balance (SSEBop) model estimates of actual evapotranspiration and irrigated acres by crop and 8-digit hydrologic unit code in the Upper Rio Grande Basin study area, 2015.-Continued

[HUC-8, 8-digit hydrologic unit code; ETa, actual evapotranspiration]

\begin{tabular}{|c|c|c|c|c|}
\hline Crop & $\begin{array}{l}\text { Irrigated acres, in } \\
\text { thousands }\end{array}$ & $\begin{array}{l}\text { ETa minimum, in } \\
\text { inches per year }\end{array}$ & $\begin{array}{l}\text { ETa maximum, in } \\
\text { inches per year }\end{array}$ & $\begin{array}{c}\text { ETa mean, in inches } \\
\text { per year }\end{array}$ \\
\hline \multicolumn{5}{|c|}{113020101} \\
\hline Alfalfa & 9.19 & 23.62 & 90.02 & 62.61 \\
\hline Apples & 0.03 & 21.93 & 38.35 & 30.94 \\
\hline Barley & 0.63 & 10.71 & 29.38 & 23.82 \\
\hline Dry beans & 0.14 & 10.81 & 23.79 & 17.97 \\
\hline Grass pasture & 9.98 & 21.86 & 87.18 & 45.40 \\
\hline Other hay/non-alfalfa & 2.33 & 13.47 & 52.26 & 33.30 \\
\hline New alfalfa & 0.07 & 13.97 & 21.29 & 17.72 \\
\hline Pecans & 0.01 & 25.94 & 33.16 & 29.83 \\
\hline Potatoes & 0.24 & 10.87 & 29.13 & 21.46 \\
\hline \multicolumn{5}{|c|}{113020201} \\
\hline Alfalfa & 0.63 & 16.30 & 56.78 & 36.65 \\
\hline Corn & 0.04 & 24.95 & 42.74 & 35.75 \\
\hline Fallow/idle cropland & 2.18 & 13.32 & 48.67 & 29.10 \\
\hline Grassland/pasture & 0.21 & 15.36 & 45.75 & 29.47 \\
\hline Irrigated turf & 0.58 & 15.23 & 46.98 & 30.33 \\
\hline Other hay/non-alfalfa & 0.25 & 20.22 & 53.13 & 38.76 \\
\hline Pecans & 0.00 & 18.80 & 18.89 & 18.86 \\
\hline \multicolumn{5}{|c|}{113020202} \\
\hline Fallow/idle cropland & 0.38 & 17.14 & 51.41 & 26.38 \\
\hline Alfalfa & 0.12 & 23.30 & 45.58 & 37.02 \\
\hline \multicolumn{5}{|c|}{113020203} \\
\hline Fallow/idle cropland & 14.35 & 6.63 & 67.01 & 35.27 \\
\hline Grapes & 0.02 & 17.07 & 36.40 & 22.61 \\
\hline Grassland/pasture & 12.93 & 6.61 & 63.78 & 35.68 \\
\hline Irrigated turf & 2.07 & 12.31 & 57.06 & 33.37 \\
\hline Lavender & 0.00 & 25.36 & 37.30 & 30.12 \\
\hline Miscellaneous vegetables and fruits & 0.00 & 16.98 & 41.25 & 31.60 \\
\hline Onions & 0.00 & 19.97 & 20.88 & 20.55 \\
\hline Other crops & 0.00 & 17.83 & 22.13 & 20.04 \\
\hline Other hay/non-alfalfa & 0.00 & 35.17 & 37.80 & 36.28 \\
\hline Other tree crops & 0.00 & 39.93 & 41.13 & 40.53 \\
\hline Pecans & 0.23 & 15.36 & 39.62 & 28.41 \\
\hline Chili peppers & 0.01 & 29.70 & 33.90 & 31.32 \\
\hline Pistachios & 0.00 & 24.28 & 33.05 & 28.31 \\
\hline Potatoes & 0.07 & 38.48 & 53.26 & 47.20 \\
\hline Triticale & 0.01 & 24.41 & 43.88 & 37.54 \\
\hline Undetermined & 0.02 & 24.09 & 42.19 & 29.83 \\
\hline
\end{tabular}


Table 11. Operational Simplified Surface Energy Balance (SSEBop) model estimates of actual evapotranspiration and irrigated acres by crop and 8-digit hydrologic unit code in the Upper Rio Grande Basin study area, 2015._-Continued

[HUC-8, 8-digit hydrologic unit code; ETa, actual evapotranspiration]

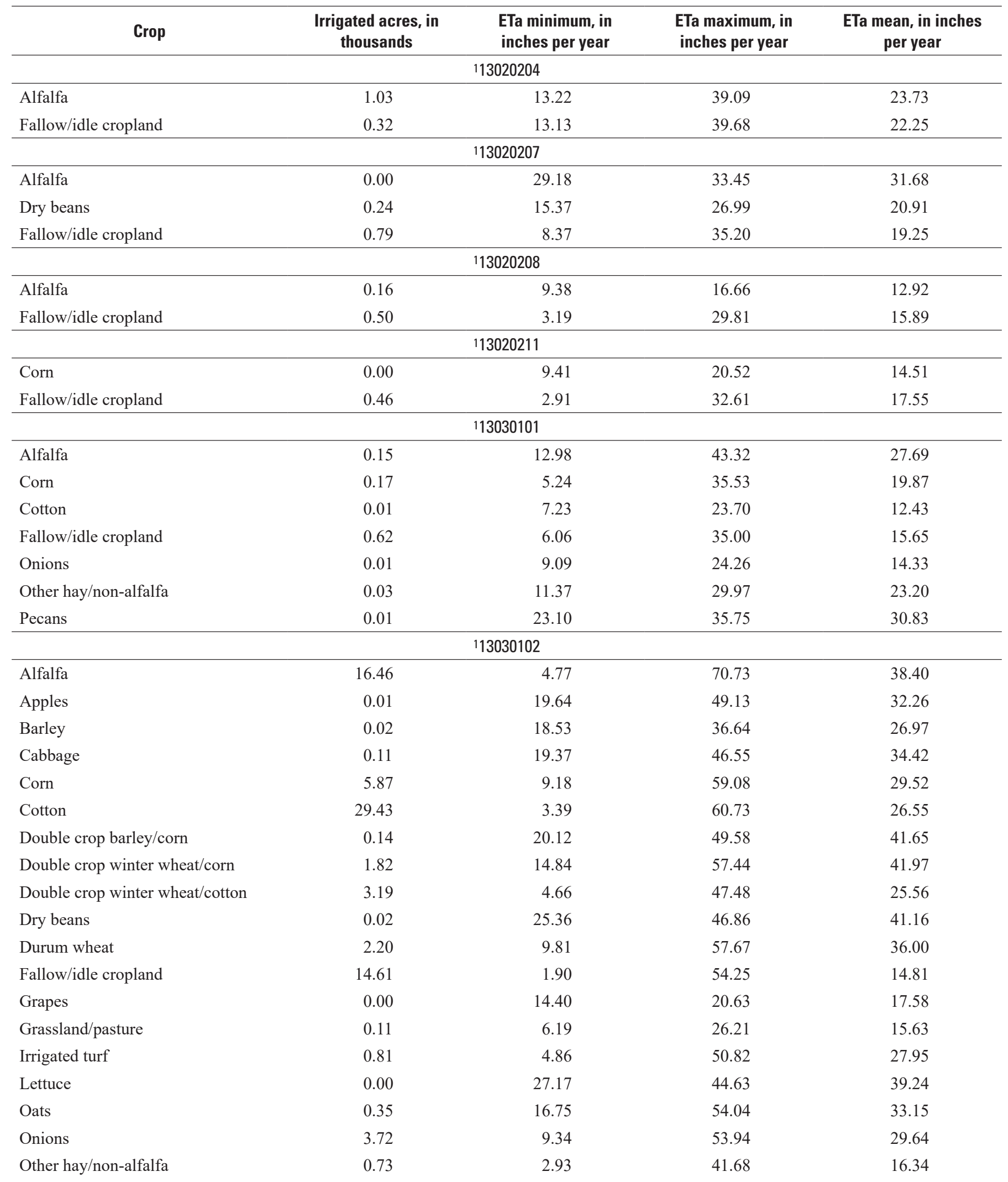


Table 11. Operational Simplified Surface Energy Balance (SSEBop) model estimates of actual evapotranspiration and irrigated acres by crop and 8-digit hydrologic unit code in the Upper Rio Grande Basin study area, 2015.-Continued

[HUC-8, 8-digit hydrologic unit code; ETa, actual evapotranspiration]

\begin{tabular}{|c|c|c|c|c|}
\hline Crop & $\begin{array}{l}\text { Irrigated acres, in } \\
\text { thousands }\end{array}$ & $\begin{array}{l}\text { ETa minimum, in } \\
\text { inches per year }\end{array}$ & $\begin{array}{l}\text { ETa maximum, in } \\
\text { inches per year }\end{array}$ & $\begin{array}{c}\text { ETa mean, in inches } \\
\text { per year }\end{array}$ \\
\hline \multicolumn{5}{|c|}{ 113030102-Continued } \\
\hline Peanuts & 0.00 & 16.31 & 18.61 & 17.46 \\
\hline Pecans & 28.83 & 1.00 & 65.60 & 42.72 \\
\hline Triticale & 0.42 & 10.67 & 45.31 & 26.58 \\
\hline Undetermined & 0.16 & 10.34 & 25.89 & 15.70 \\
\hline Watermelons & 0.49 & 9.31 & 41.34 & 27.61 \\
\hline Winter wheat & 2.26 & 3.14 & 54.79 & 24.67 \\
\hline \multicolumn{5}{|c|}{113040100} \\
\hline Alfalfa & 14.51 & 3.86 & 61.12 & 35.84 \\
\hline Alfalfa/cotton & 0.05 & 33.11 & 47.10 & 40.03 \\
\hline Apples & 0.02 & 37.31 & 48.77 & 43.51 \\
\hline Cotton & 32.29 & 7.14 & 59.28 & 30.43 \\
\hline Double crop winter wheat/cotton & 0.09 & 20.16 & 33.26 & 28.16 \\
\hline Fallow/idle cropland & 25.83 & 6.14 & 77.90 & 19.13 \\
\hline Grassland/pasture & 0.15 & 21.00 & 46.05 & 33.69 \\
\hline Irrigated turf & 1.19 & 6.19 & 65.88 & 29.34 \\
\hline Sorghum & 0.07 & 25.70 & 42.70 & 32.74 \\
\hline Winter wheat & 0.13 & 19.60 & 37.71 & 28.54 \\
\hline
\end{tabular}

1HUC-8 in the Upper Rio Grande Basin study area are shown in figure 1. 
To summarize ETa crop data across the study area, a mean of the simulated crop mean ETa was calculated from values in table 11 and reported here. The mean of the mean ETa for crops was highest for durum wheat at 36.00 inches per year (in/yr) and lowest for vegetables at $19.48 \mathrm{in} / \mathrm{yr}$. The mean ETa of alfalfa and irrigated grass pastures had overall means of 31.4 and $27.58 \mathrm{in} / \mathrm{yr}$, respectively, for the study area. Pecans and chili peppers, both signature crops in the Rio Grande Basin, had means of 30.67 and $30.38 \mathrm{in} / \mathrm{yr}$, respectively, of mean ETa.

In general, crop mean ETa values were lower in the Colorado San Luis Valley, at HUCs 13010001, 13010002, 13010003 and 13010004, which are more northerly and at higher elevations. The mean ETa for crops increased in the HUCs that are more southerly and at lower elevations in the basin. A good ubiquitous crop to compare across the basin is alfalfa; in a San Luis Valley, Colorado HUC (13010001) mean ETa was 24.24 in/yr compared to $35.84 \mathrm{in} / \mathrm{yr}$ in the Fort Quitman, Texas HUC (13040100) (table 11).

Alfalfa, grown across the basin, can also be used to compare mean ETa between irrigation system types, eliminating the influence of crop type. Table 12 lists ETa and irrigated acres for surface and sprinkler irrigation system types in the select HUC-8s. In HUCs 13010002, 13010003, and 13010004 in the ancillary irrigation data for Colorado, no distinction was made between sprinklers and pivot sprinklers or between flood and furrow surface irrigation system types. When pivot sprinklers and flood irrigation systems for alfalfa are compared, except for HUC 13030102 (this is one of the HUCs that extends into Mexico), the sprinkler-irrigated acres in the URGB yielded higher mean ETa than the surface-irrigated acres. An explanation for differences in HUC 13030102 could not be described because information on agricultural practices in Mexico is unknown. In HUC 13030102, the difference between mean flood ETa and pivot sprinkler ETa is $3.30 \mathrm{in} / \mathrm{yr}$. The flood surface irrigation system mean ETa is greater than the pivot sprinkler mean by a difference of 8.91 percent (table 12). HUC 13030102 also had the highest maximum mean ETa for alfalfa of the selected HUCs, at $70.73 \mathrm{in} / \mathrm{yr}$ for the flood irrigation system type.

In California, higher ETa for irrigated crops was reported for fields irrigated using the more efficient methods of irrigating crops (microirrigation or drip) than for fields irrigated by flood (Burt and others, 2001). Burt and others (2001) suggest that the microirrigation or drip systems are designed to reduce plant stress and provide a small but steady amount of water to the crop, thereby keeping the soil immediately around the plant almost continuously wet, which adds to the soil evaporation component of ET. In contrast, although water applied by surface flood and furrow irrigation methods wets more of the soil in a field, the soil dries between applications, potentially decreasing the amount of soil evaporation. Sprinkler-applied irrigation water results in a higher evaporation component of ET, because in addition to the wetted soil surface (as in furrow irrigation methods), plant surfaces and leaves are also wetted (Burt and others 2001).
An analysis of leaf and soil temperatures for test fields of corn in Kansas by Steiner and others (1983) reported that sprinklers cooled the plants in comparison to surface systems by $1{ }^{\circ} \mathrm{C}$ for a daily mean temperature. Soil temperatures were cooler (also by $1{ }^{\circ} \mathrm{C}$ as a mean daily temperature) under the sprinkler irrigation than under surface irrigation methods. These temperature variations can likely affect SSEBop ETa because the Landsat thermal band includes surface temperatures. Steiner and others (1983) implied that, with lower leaf temperatures in the sprinkler system fields, transpiration rates (in addition to soil and plant-surface evaporation rates) between sprinkler and surface irrigated fields were likely different.

Senay and others (2019) reported an ETa anomaly for 2015 in the San Luis Valley, where the ETa sharply decreased in the eastern section of the valley. Multiple center pivots showed this reduction (fig. 9). Factors including economics, cropping patterns, and soil types likely contribute to the pattern of lower ETa in the eastern section of the valley in comparison to the western section. Irrigators on the eastern side of the valley may utilize 3-6 wells for a center pivot irrigation system irrigating about 125 acres, whereas on the western side of the valley irrigators operate only 1-2 wells for 125 acres. Soil types on the eastern side of the San Luis Valley in general contain more clay, requiring multiple wells to irrigate crops. With the additional wells, water production is often not enough to irrigate the entire 125 acres. Many farmers on the eastern side of the valley only irrigate half of the land under a center pivot (Craig Cotten, Colorado Division of Water Resources, Division 3 Engineer, written commun., 2020).

Figure 9 shows more partially irrigated parcels on the eastern side of the valley than on the western side. Farmers on the eastern side of the valley plant more potatoes, cover crops, and barely, whereas the farmers on the western side grow hay and alfalfa (Craig Cotten, Colorado Division of Water Resources, Division 3 Engineer, written commun., 2020). Both hay and alfalfa require more water to mature (see table 11) than what may be available on the eastern side of valley. Many irrigators on the eastern side of the valley do not have water rights or access to surface water and rely solely on groundwater for irrigation water, whereas farms in the central and western side of the valley have surface water in addition to the groundwater sources (Craig Cotten, Colorado Division of Water Resources, Division 3 Engineer, written commun., 2020). Finally, farmers on the eastern side of the valley in the Rio Grande Water Conservation District subdistrict 1 (Rio Grande Water Conservation District, 2020) began being charged for pumping groundwater in 2012 , as part of the effort to control the declining aquifer water levels in the valley. However, charges for pumping groundwater could be offset by using surface water, which is not readily available to the irrigators on the eastern side of the valley. Irrigators on the western side use surface water to negate the groundwater pumping fees whereas irrigators on the eastern side, with access to little or no surface water, pay more to grow crops. Eastern valley farms often operate by deficit irrigation more than in the central or western side of the valley (Craig Cotten, Colorado Division of Water Resources, Division 3 Engineer, written commun., 2020). 
Table 12. Operational Simplified Surface Energy Balance (SSEBop) model estimates of actual evapotranspiration and irrigated acres for alfalfa by irrigation system type in select 8-digit hydrologic unit codes in the Upper Rio Grande Basin study area, 2015.

[HUC-8, 8-digit hydrologic unit code; ET, evapotranspiration; - , data not available]

\begin{tabular}{|c|c|c|c|c|c|}
\hline System type & $\begin{array}{l}\text { Irrigated acres, in } \\
\text { thousands }\end{array}$ & $\begin{array}{l}\text { ET minimum, in } \\
\text { inches per year }\end{array}$ & $\begin{array}{l}\text { ET maximum, in } \\
\text { inches per year }\end{array}$ & $\begin{array}{c}\text { ET mean, in inches } \\
\text { per year }\end{array}$ & $\begin{array}{l}\text { Percent difference } \\
\text { ET mean, system type }\end{array}$ \\
\hline \multicolumn{6}{|c|}{113010002} \\
\hline Surface & 27.80 & 4.70 & 38.63 & 223.13 & 16.57 \\
\hline Sprinkler & 60.73 & 7.97 & 43.61 & 227.31 & - \\
\hline \multicolumn{6}{|c|}{113010003} \\
\hline Surface & 5.91 & 6.71 & 26.71 & 217.16 & 33.52 \\
\hline Sprinkler & 18.21 & 4.71 & 37.14 & 224.07 & - \\
\hline \multicolumn{6}{|c|}{113010004} \\
\hline Flood/Surface & 4.76 & 10.85 & 36.78 & 224.96 & 8.49 \\
\hline Sprinkler & 17.14 & 7.60 & 40.86 & 227.17 & - \\
\hline \multicolumn{6}{|c|}{113020203} \\
\hline Flood & 17.18 & 8.76 & 67.99 & 239.09 & 0.72 \\
\hline Pivot Sprinkler & 0.89 & 21.85 & 47.85 & 239.37 & - \\
\hline Sprinkler & 0.00 & 21.11 & 33.57 & 29.14 & - \\
\hline \multicolumn{6}{|c|}{113030102} \\
\hline Furrow & 1.47 & 5.91 & 59.56 & 37.53 & - \\
\hline Flood & 14.22 & 4.77 & 70.73 & 238.67 & 8.91 \\
\hline Pivot Sprinkler & 0.75 & 8.86 & 61.97 & 235.37 & - \\
\hline Sprinkler & 0.02 & 17.16 & 32.63 & 25.62 & - \\
\hline
\end{tabular}

${ }^{1}$ HUC-8 in the Upper Rio Grande Basin study area are shown in figure 1.

2Data used in percent difference calculation.

\section{Summary}

The Rio Grande flows approximately 670 miles from its headwaters in the San Juan Mountains of south-central Colorado to Fort Quitman, Texas, draining the Upper Rio Grande Basin (URGB) study area of 32,000 square miles that includes parts of Colorado, New Mexico, and Texas. Parts of the basin extend into Mexico, where the Rio Grande forms the international boundary between Texas and the State of Chihuahua. The URGB was chosen as a focus area study for the U.S. Geological Survey (USGS) National Water Census (NWC) as part of the WaterSMART initiative. The objective of the USGS NWC under WaterSMART is to focus on the technical aspects of providing information and tools to stakeholders so that they can make informed decisions on water availability.

This report contains water-use estimates of public-supply, self-supplied domestic, and irrigation water use from 1985 to 2015 at 5-year intervals for the 22 drainage basins at the subbasin 8-digit hydrologic unit code (HUC-8) level. In addition to the three water-use categories, self-supplied industrial, mining, livestock, aquaculture, thermoelectric, and hydroelectric water use estimates at the HUC-8 level for 2015 are presented to illustrate total withdrawals for the basin. Water withdrawals for all the water-use categories 1985-2015 are provided in a data release; however, water use data for public-supply, selfsupplied domestic and irrigation are tabulated and presented in this report. Withdrawal data for 2015 water-use categories of self-supplied industrial, mining, livestock, aquaculture, thermoelectric, and hydroelectric are tabulated and presented only in the data release. The withdrawals represent groundwater and surface water for the categories of use. Deliveries of water from public-supply systems to domestic users are included and are the only water delivery data presented in this report. Consumptive use for irrigation is reported for all HUC-8s for 2015 and for select HUC-8s in the other years (the irrigation category includes irrigation for both crop and golf). Water transported outside of the URGB (interbasin transfers) is not included as part of the withdrawals and are not accounted for in any category of use within the URGB.

Methods used to compile water-use data in the URGB Focus Area Study are the same as those used for the USGS national water-use compilations. The national compilations contain spatially varying aggregated data using information collected by numerous private, local, State, and Federal entities, and standard methods and techniques to compile and 


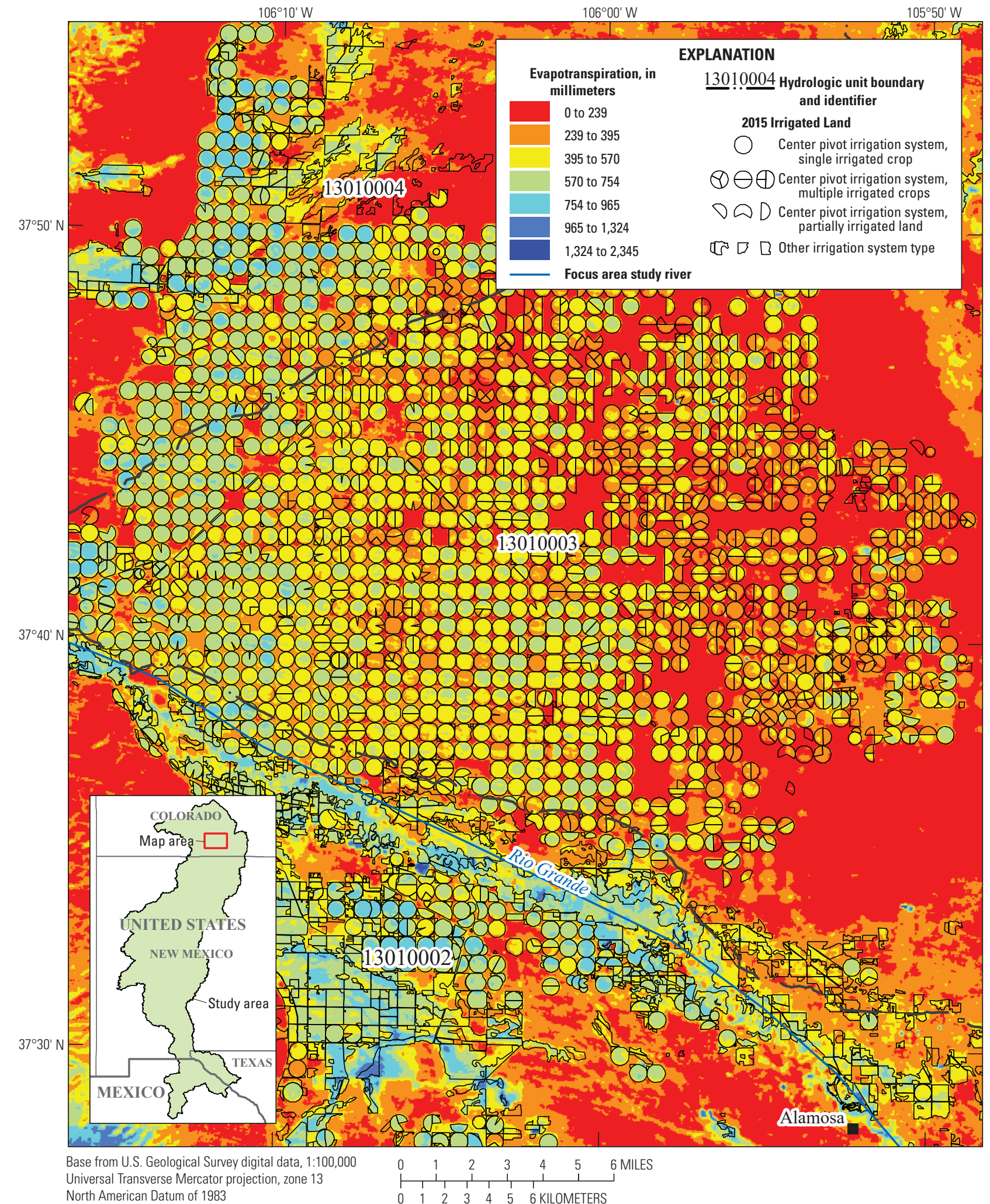

Figure 9. Annual evapotranspiration for 2015 in the San Luis Valley, Colorado. 
aggregate these data by HUC-8 have been in use since 1995 . Both reported and estimated withdrawal data from 1985 to 2015 are aggregated to HUC-8 in this report by category, by State, in 5-year intervals.

Estimated total withdrawals for all the water-use categories (including hydroelectric) in 2015 as reported in the USGS compilations in the URGB were 3,152.10 million gallons per day (Mgal/d). Surface water was the dominant source of water used in the URGB, providing about 71 percent of total withdrawals. Nearly all withdrawals were from freshwater sources; a small amount of saline groundwater was withdrawn for publicsupply and self-supplied industrial use in Texas. A comparison of 2015 water withdrawals for the URGB, for the categories of public supply, self-supplied domestic, self-supplied industrial, thermoelectric, irrigation, livestock, mining, aquaculture, and hydroelectric, shows that irrigation at 74 percent is the dominant water-use category. Other water-use categories in the URGB about 1 percent or greater of the total water use by volume are public supply ( 9 percent), self-supplied domestic (1 percent), and aquaculture (1 percent). This report focuses on the higher volume, consumptively used categories of public supply, selfsupplied domestic, and irrigation. A discussion on basin population provides context for the categories of public-supply and self-supplied domestic water use.

The population in the part of the basin in the United States grew from 1.36 to 2.26 million people between 1985 and 2015. With Ciudad Juarez, Mexico, included, the total population of the URGB had an estimated 2.01 million people in 1985, increasing to 3.66 million in 2015. The concentrations of population are located in New Mexico, Texas, and Mexico, with 98 percent of the total number of people in the basin in 1985 and 99 percent of the total in 2015 located in these states and country.

Public-supply withdrawals provided most of the potable water supply, which could be used for indoor or outdoor purposes. Total withdrawals for public supply in the URGB had a mean of about $277 \mathrm{Mgal} / \mathrm{d}$ from 1985 to 2015, ranging from $231.14 \mathrm{Mgal} / \mathrm{d}$ in 1985 to $328.66 \mathrm{Mgal} / \mathrm{d}$ in 1995 . Most of the URGB total public-supply withdrawals are in New Mexico, about 60 percent of the total, and averaged $170 \mathrm{Mgal} / \mathrm{d}$. No complete set of data was available from the Junta Municipal de Agua y Saneamiento for Ciudad Juarez, Mexico, to include in the total withdrawals for HUCs 13030103 and 13040100.

Within the URGB, groundwater is the predominant source of water for public supply. Groundwater provided about 70 and 93 percent (in 2015 and 1985, respectively) of the total withdrawals in the study area for municipal use. Surface-water withdrawals increased in New Mexico from $4.99 \mathrm{Mgal} / \mathrm{d}$ in 2005 to $51.55 \mathrm{Mgal} / \mathrm{d}$ in 2015 . These increases can be attributed to the water from the San Juan-Chama Project which, in 2015, decreased the percentage of groundwater use in the New Mexico part of the URGB to 67 percent of the total withdrawals. The City of El Paso, the largest public supplier in the Texas part of the URGB, relies on the Rio Grande to supplement groundwater for municipal use. Groundwater still supplied between 53 and 100 percent of the withdrawals from
1985 to 2015 in Texas. Because of limited surface water and increasingly limited fresh groundwater that must be shared with Mexico, the City of El Paso, in cooperation with Fort Bliss U.S. Army post, invested in a desalination plant. In 2010 and 2015, 55.16 and $9.12 \mathrm{Mgal} / \mathrm{d}$, respectively, of saline groundwater for public-supply water use were reported as withdrawals in the Texas part of the URGB.

In the URGB, domestic deliveries from public suppliers increased from 1985 to 1995; since 2005, domestic deliveries from public supply have declined. The percentage of people on public-supply systems in the URGB ranged from 81 to 92 percent from 1985 to 2015 . Total domestic withdrawals in the URGB (deliveries plus self-supply withdrawals) ranged from about 177.49 to $234.83 \mathrm{Mgal} / \mathrm{d}$ with the peak year in 2005. Domestic use decreased from 2005 to 2010 by 17 percent and remained less than $200 \mathrm{Mgal} / \mathrm{d}$ in 2015 . The per-capita daily use for the entire URGB fluctuated between the reporting years, but overall, domestic per-capita use across the basin has declined 46 percent from 145 gallons per-capita daily (gpcd) in 1985 to 79 gpcd in 2015.

Total irrigation withdrawals in the URGB had a mean of 2,767.66 Mgal/d from 1985 to 2015, and withdrawals peaked in 1995 at 3,416.84 Mgal/d. Irrigation source water in the URGB has been 67-86 percent surface water, and the most surface water diverted in the basin for irrigation was in 1995. Over the 30-year period, groundwater withdrawals fluctuated but decreased between 2005 and 2015 by 13 percent. In the URGB, reclaimed wastewater is used to supplement irrigation for golf courses, parks, school grounds, apartment landscapes, construction, and industrial sites. Reclaimed wastewater used for irrigation in 1985 and 2015 totaled 0.39 and $13.30 \mathrm{Mgal} / \mathrm{d}$, respectively, and all reported use was in New Mexico and Texas. Slightly more than one-half of total irrigation withdrawals within the URGB from 1985 to 2015 occurred in Colorado, with a mean of 57 percent, compared to 36 percent in New Mexico and 7 percent in Texas. From the peak of water withdrawals in 1995 to the conclusion of this study in 2015, total irrigation withdrawals across the Upper Rio Grande study area decreased by 32 percent.

The number of total irrigated lands from 1985 to 2015 in the URGB had a mean of about 800 thousand acres, and more irrigated lands were consistently located in the headwaters of the URGB in the San Luis Valley in Colorado than in the remainder of the study basin. Colorado had a mean of 68 percent of total irrigated lands in the basin and ranged from about 484 thousand acres (1995) to 578 thousand acres (1990). Irrigated acres in New Mexico had a mean of 26 percent of the total number of irrigated acres in the basin, and the remaining 7 percent were in Texas. Since 2000, the number of irrigated acres in the URGB has fluctuated in the 15-year period; however, overall, the number of irrigated acres has decreased by 12 percent. More lands were irrigated with surface systems than other irrigation system types in the URGB, ranging from 62 to 88 percent of total irrigated lands and had a mean of 69 percent of the acres across the 30-year period. Microirrigation systems composed 0.2 percent or less of the irrigated acres in the basin. These systems are only located in 
New Mexico and Texas and were first reported in 1995. Surface irrigation in the Colorado part of the URGB has decreased from about 480 thousand acres in 1985 to about 237 thousand acres in 2015 , a decrease of 51 percent. Acres irrigated by sprinkler systems (predominately center pivot systems) have increased 179 percent from about 99 thousand acres in 1985 to 275 thousand acres in 2015.

Evapotranspiration (ET) is the combination of evaporation from free-water surfaces and transpiration through plants. The two separate evaporative processes are typically combined in the single term, ET, because both processes contribute to evaporative losses from most vegetative land surfaces, and it is difficult to measure the two processes independently. A number of methods can be used to estimate ET or potential ET at a variety of temporal and spatial scales. Three of these methods have been applied and compared to the Landsat-based Operational Simplified Surface Energy Balance (SSEBop) method which calculates actual ET [ETa] in the URGB: the Moderate Resolution Imaging Spectroradiometer (MODIS)-based SSEBop (Colorado), Original Blaney-Criddle (OBC) (New Mexico), and an irrigation-rate based estimation method (Texas). The New Mexico HUC-8 water-use estimates that were calculated using the $\mathrm{OBC}$ method are higher than the Landsat-based SSEBop results (by a mean of 56 percent in HUC-8s that are located only in New Mexico). This difference is expected because the two methods represent different field conditions. The OBC method calculates an "ideal" crop irrigation requirement, whereas the SSEBop model calculates an "actual" crop water use. The HUC-8 water-use estimates in Colorado from the MODIS-based SSEBop data vary widely by HUC; the MODIS-based water use estimate is lower in one HUC (13010004) but higher than estimates from the Landsat-based SSEBop data in the other HUCs by a mean of 18 percent (in HUC-8s that are located only in Colorado). The HUC-8 water-use estimates in Texas are higher than the Landsat-based SSEBop results. There is only one HUC-8 located solely in Texas (13040100), and the two water-use estimates in this HUC have a 39-percent difference.

In 2015, the five primary crops or forage grown in the URGB based on number of irrigated acres (in decreasing order of total irrigated acres) were as follows: grass pastures (236 thousand acres), alfalfa (228 thousand acres), barley (65.5 thousand acres), cotton (61.7 thousand acres), and potatoes (54.5 thousand acres). Other important crops in the basin include pecans (41.7 thousand acres), small grains (7.3 thousand acres), onions (3.8 thousand acres), and vegetables (2.9 thousand acres). In 2015, there were an estimated 1.63 thousand acres identified as chili peppers, grown in HUCs 13020203 and 13030102.

The simulated mean ETa for crops across the study area was highest for durum wheat at an estimated 36.00 inches per year (in/yr) and was lowest for vegetables at an estimated $19.48 \mathrm{in} / \mathrm{yr}$. The mean ETa of alfalfa and irrigated grass pastures had an overall mean of 31.4 and $27.58 \mathrm{in} / \mathrm{yr}$, respectively, for the basin. Pecans and chili peppers, both signature crops in the Rio Grande Basin, had means of 30.67 and $30.38 \mathrm{in} / \mathrm{yr}$, respectively, of mean ETa. In general, mean ETa values were lower in the Colorado San Luis Valley HUCs which are more northerly and at higher elevations: 13010001, 13010002, 13010003, and 13010004. Mean ETa for crops increased in the HUCs that are more southerly and at lower elevations in the basin. A good crop to compare ETa between the HUC- 8 basins is alfalfa; in HUC 13010001, the mean ETa was $24.24 \mathrm{in} / \mathrm{yr}$ and in the Fort Quitman HUC (13040100) in Texas, the mean ETa was $35.84 \mathrm{in} / \mathrm{yr}$.

\section{References Cited}

Abatzoglou, J.T., 2013, Development of gridded surface meteorological data for ecological applications and modelling: International Journal of Climatology, v. 33, no. 1, p. 121-131. [Also available at https://doi.org/10.1002/joc.3413.]

Albuquerque Bernalillo County Water Utility Authority, 2019a, Your drinking water-San Juan Chama Project: Albuquerque Bernalillo County Water Utility Authority, accessed June 27, 2019, at https://www.abcwua.org/ San_Juan_Chama_Project.aspx.

Albuquerque Bernalillo County Water Utility Authority, 2019b, Conservation and rebates - Outdoor rebates: Albuquerque Bernalillo County Water Utility Authority, accessed July 8, 2019, at https://www.abcwua.org/Outdoor_Rebates.aspx.

Arizona Department of Water Resources, 2019, Water supply of the Southeastern Arizona Planning Area-Surface water: Arizona Department of Water Resources, accessed June 16, 2020 at https://repository.asu.edu/items/14157.

Blaney, H.F., and Criddle, W.D., 1950, Determining water requirements in irrigated areas from climatological and irrigation data, TP-96: Washington, D.C., U.S. Department of Agriculture Soil Conservation Service.

Blankenbuehler, P., 2016, After years of drought and overuse, the San Luis Valley aquifer refills: High Country News, accessed May 26, 2016, at https://www.hon.org/articles/ after-years-of-drought-and-overuse-a-water-basin-refills-inthe-san-luis-valley.

Bowlin, N., 2019, Colorado farmers fight to save their water and their community's future: High Country News, accessed October 8, 2019, at https://coyotegulch.blog/category/ colorado-water/san-luis-valley-groundwater/.

Bradley, M.W., comp., 2017, Guidelines for preparation of State water-use estimates for 2015: U.S. Geological Survey Open-File Report 2017-1029, 54 p. [Also available at https://doi.org/10.3133/ofr20171029.]

Bureau of Reclamation [Reclamation], 2018a, Rio Grande Project: Bureau of Reclamation, Projects and Facilities, accessed October 31, 2018, at https://www.usbr.gov/ projects/index.php?id=397. 
Bureau of Reclamation [Reclamation], 2018b, Middle Rio Grande Project: Bureau of Reclamation, Projects and Facilities, accessed October 31, 2018, at https://www.usbr.gov/projects/index.php?id=508.

Burt, C.M., Howes, D.J. and Mutziger, Andrew, 2001, Evaporation estimates for irrigated agriculture in California, in Irrigation Association Conference, San Antonio, Tex., Proceedings: Irrigation Training and Research Center, Paper no. P01-002, p. 103-110, accessed February 10, 2020, at http://www.itrc.org/papers/pdf/evaporationestimates.pdf

City of El Paso, 2005, PdnMapa Interactive Mapping, Paso del Norte Mapa: City of El Paso, accessed April 20, 2016, at http:/gis.elpasotexas.gov/pdnmapajs/

City of Las Cruces Water Division, 2019, Water conservation resources: City of Las Cruces, accessed July 8, 2019, at https://www.las-cruces.org/1292/Water-Conservation-Resources

Colorado Decision Support System, 2016 GIS Data: State of Colorado, accessed September 21, 2016, at https://www.colorado.gov/pacific/cdss/gis-data.

Colorado Decision Support System, 2019, StateCU: State of Colorado, accessed July 24, 2019, at https://www.colorado.gov/pacific/cdss/statecu.

Colorado Division of Water Resources, 2018, Colorado's surface water conditions: Colorado Division of Water Resources, accessed November 8, 2018, at https://www.dwr.state.co.us/SurfaceWater/default.aspx.

Deere and Ault Consultants, Inc., 2018, Rio Grande dam and reservoir rehabilitation: Deer and Ault Consultants, Inc., accessed October 31, 2018, at https://deereault.com/ dam-reservoir-design/rio-grande-reservoir.php.

Dieter, C.A., Maupin, M.A., Caldwell, R.R., Harris, M.A., Ivahnenko, T.I., Lovelace, J.K., Barber, N.L., and Linsey, K.S., 2018, Estimated use of water in the United States in 2015: U.S. Geological Survey Circular 1441, 65 p. [Supersedes USGS Open-File Report 2017-1131] [Also available at https://doi.org/10.3133/cir1441.]

El Paso Water, 2019a, Desalination: El Paso Water, accessed June 28, 2019, at https://www.epwater.org/our_water/water_ resources/desalination.

El Paso Water, 2019b, Our history of conservation: El Paso Water, accessed July 24, 2019, at https:/www.epwater.org/ conservation/Billions_of_Gallons_Saved.

El Paso Water, 2019c, Report water waste: El Paso Water, accessed July 24, 2019, at https://www.epwater.org/ conservation/report_water_waste.

El Paso Water, 2019d, Reclaimed water: El Paso Water, accessed July 24, 2019, at https://www.epwater.org/cms/ one.aspx?portalId=6843488\&pageId $=7416458$.
ESRI, 2020, How zonal statistics work: ESRI, accessed January 21, 2020, at https://desktop.arcgis.com/en/arcmap/10.3/ tools/spatial-analyst-toolbox/h-how-zonal-statistics-works.htm.

Farr, T.G., and Kobrick, M., 2000, Shuttle radar topography mission produces a wealth of data: Eos (Washington, D.C.), v. 81 , no. 48 , p. 583-585. [Also available at https://doi.org/ 10.1029/EO081i048p00583.]

Food and Agricultural Organization of the United Nations, 1986, Irrigation water needs, in Brouwer, C., and Heibloem, M., eds., Irrigation water management-Training manual no. 3: Rome, Italy, Food and Agricultural Organization of the United Nations Land and Water Development Division.

Franceschini, A., and Tucker, D., 2010, Farm together now-A portrait of people, places and ideas for a new food movement: San Francisco, Calif., Chronicle Books, accessed October 31, 2018, at https://farmtogethernow.files.wordpress.com/2010/ 04/joegallegosanddevonpena-farmtogethernow.pdf.

Heywood, C.E., and Yager, R.M., 2003, Simulated groundwater flow in the Hueco Bolson, an alluvial-basin aquifer system near El Paso, Texas: U.S. Geological Survey WaterResources Investigations Report 02-4108, 73 p. [Also available at https://doi.org/10.3133/wri024108.]

Hurd, B.H., 2010, Water-conserving attitudes and landscape choices in New Mexico: Choices Magazine, accessed July 8, 2019, at https://www.choicesmagazine.org/ magazine/article.php? article $=146$.

Indian Pueblo Cultural Center, 2020, New Mexico's 19 Pueblos, accessed November 23, 2020, at https://indianpueblo.org/new-mexicos-19-pueblos/.

International Boundary and Water Commission, 2020, About the Rio Grande: International Boundary and Water Commission, accessed August 18, 2020, at https://www.ibwc.gov/CRP/riogrande.htm.

International Boundary and Water Commission, 2018, Rio Grande water flows: International Boundary and Water Commission, accessed November 8, 2018, at https://www.ibwc.gov/Water_Data/rio_grande_ WF.html\#Stream.

Irons, J.R., Dwyer, J.L., and Barsi, J.A., 2012, The next Landsat satellite - The Landsat data continuity mission: Remote Sensing of Environment, v. 122, p. 11-21. [Also available at https://doi.org/10.1016/j.rse.2011.08.026.]

Ivahnenko, Tamara, and Galanter, A.E., 2021, Estimated use of water by subbasin (HUC8) in the Upper Rio Grande Basin, 1985-2015: U.S. Geological Survey data release, https://doi.org/10.5066/F7SX6CJ2/. 
Jensen, M.E., Burman, R.D., and Allen, R.G., 1990, Evapotranspiration and irrigation water requirements: New York, American Society of Civil Engineers Manuals and Reports on Engineering Practice, no. 70, 332 p.

Llewellyn, D., and Vaddey, S., 2013, West-wide climate risk assessment-Upper Rio Grande impact assessment: Albuquerque, N. Mex., Bureau of Reclamation, 138 p.

Magnuson, M.L., Valdez, J.M., and Lawler, C.R., Nelson, Matt and Petronis, Laura, 2019, New Mexico water use by categories - 2015: New Mexico Office of the State Engineer, Technical Report 55, 126 p., accessed July 2, 2019, at https://www.ose.state.nm.us/WUC/wucTechReports/2015/ pdf/2015\%20WUR\%20final_05142019.pdf.

Maupin, M.A., Senay, G.B., Kenny, J.F., and Savoca, M.E., 2012, A comparison of consumptive-use estimates derived from the simplified surface energy balance approach and indirect reporting methods: U.S. Geological Survey Scientific Investigations Report 2012-5005, 8 p. [Also available at https://doi.org/10.3133/sir20125005.]

National Park Service, 2018, Visiting New Mexico pueblos: Albuquerque, N. Mex, National Park Service, accessed October 31, 2018, at https://www.nps.gov/petr/ planyourvisit/pueblos.htm.

National Water and Climate Center, 2018, Climate analysis for wetlands by county: Natural Resources Conservation Service, accessed December 21, 2018, at https://www.wcc.nrcs.usda.gov/climate/wets_doc.html.

Pedraza, D.E., Stengel, V.G., Pasley, N. and Pease, E.C., 2019, 2015 irrigated acres feature class for the Upper Rio Grande Basin, New Mexico, Texas, United States and Chihuahua, Mexico: U.S. Geological Survey data release, https://doi.org/https://doi.org/10.5066/P99OIFYY.

Pochop, L.O., Borrelli, John and Burman, R. D., 1984, Elevation - a bias error in SCS Blaney Criddle ET estimates, Transactions of the Soil and Water Division, ASAE accessed July 24, 2019, at http://www.ids.colostate.edu/ projects/idscu/files/pochop.pdf.

PRISM Climate Group, 2017, PRISM climate data: Oregon State University, accessed July 20, 2019, at http://prism.oregonstate.edu.

Rio Grande Water Conservation District, 2020, Subdistricts: Rio Grande Water Conservation District, accessed January 29, 2020, at https://www.rgwed.org/subdistricts.

Sargent, B.P., Houston, N.A., and Heal, E.N., 2020, Estimated use of water by subbasin (HUC8) in the Red River Basin, 2010 and 2015: U.S. Geological Survey data release, https://doi.org/10.5066/P9SQ1Y3T.
Save Water Santa Fe, 2019, Outdoor rebates: City of Santa Fe Water Conservation, Santa Fe Water Conservation Office, accessed July 8, 2019, at https://savewatersantafe.com/ outdoor-rebates/

Savoca, M.E., Senay, G.B., Maupin, M.A., Kenny, J.F., and Perry, C.A., 2013, Actual evapotranspiration modeling using the operational Simplified Surface Energy Balance (SSEBop) approach: U.S. Geological Survey Scientific Investigations Report 2013-5126, 16 p. [Also available at https://doi.org/10.3133/sir20135126.]

Seaber, P.R., Kapinos, F.P., and Knapp, G.L., 1987, Hydrologic unit maps: U.S. Geological Survey WaterSupply Paper 2294, 20 p., 1 pl. [Also available at https://pubs.usgs.gov/wsp/wsp2294/pdf/wsp_2294_a.pdf.]

Senay, G.B., 2018, Technical Note-Satellite psychrometric formulation of the Operational Simplified Surface Energy Balance (SSEBop) model for quantifying and mapping evapotranspiration: Applied Engineering in Agriculture, v. 34, no. 3, p. 555-566. [Also available at https://doi.org/10.13031/aea.12614.]

Senay, G.B., Bohms, Stefanie, Singh, R.K., Gowda, P.H., Velpuri, N.M., Alemu, Henok, and Verdin, J.P., 2013, Operational evapotranspiration modeling using remote sensing and weather datasets-A new parameterization for the SSEB ET approach: Journal of the American Water Resources Association, v. 49, no. 3, p. 577-591. [Also available at https://doi.org/10.1111/jawr.12057.]

Senay, G.B., Friedrichs, M.K., Singh, R.K., and Velpuri, N.M., 2016, Evaluating Landsat 8 evapotranspiration for water use mapping in the Colorado River Basin: Remote Sensing of Environment, v. 185, p. 171-185, accessed October 2, 2019. https://doi.org/10.1016/j.rse.2015.12.043.

Senay, G.B., Schauer, M.P., Velpuri, N.M., Singh, R.K., Kagone, S., and Friedrichs, M.O., 2018, Upper Rio Grande River Basin SSEBop monthly sum actual evapotranspiration (ET) 1984-2015: Sioux Falls, S. Dak., USGS Earth Resources Observation and Science (EROS) Center, accessed January 22, 2019, at https://doi.org/10.5066/P9V6DS94.

Senay, G.B., Schauer, M., Velpuri, N.M., Singh, R.K., Kagone, S., Friedrichs, M., Litvak, M.E., and Douglas-Mankin, K.R., 2019, Long-term (1986-2015) water use characterization over the Upper Rio Grande Basin using Landsat-based evapotranspiration: Remote Sensing, v. 11, no. 13, 25 p., accessed December 2, 2019, at https://doi.org/10.3390/rs11131587.

Singh, R.K., Senay, G.B., Velpuri, N.M., Bohms, S., Scott, R.L., and Verdin, J.P., 2014, Actual evapotranspiration (water use) assessment of the Colorado River Basin at the Landsat resolution using the Operational Simplified Surface Energy Balance model: Remote Sensing, v. 6, no. 1, p. 233-256, accessed October 2, 2019. https://doi.org/10.3390/rs6010233. 
Solley, W.B., Pierce, R.R., and Perlman, H.A., 1998, Estimated use of water in the United States in 1995: U.S. Geological Survey Circular 1200, 71 p. [Also available at https://doi.org/10.3133/cir1200.]

Steiner, J.L., Kanemasu, E.T., and Hasza, D., 1983, Microclimatic and crop responses to center pivot sprinkler and to surface irrigation: Irrigation Science, v. 4, no. 3, p. 201-214, accessed February 10, 2020. https://doi.org/ 10.1007/BF00285526.

The Weather Channel, 2020, Creede, CO monthly weather: The Weather Channel, accessed April 3, 2020, at https://weather.com/weather/monthly/1/Creede+CO? canonicalCityId=c2ec1ae31a306e60c9dc4bea827584e8bf 945061d17a0220fddef730d3d6f37f.

Thornton, P.E., Thornton, M.M., Mayer, B.W., Wilhelmi, N., Wei, Y., Devarakonda, R., and Cook, R.B., 2014, Daymet - Daily surface weather data on a 1-km grid for North America, Version 2: Oak Ridge, Tenn., Oak Ridge National Laboratory Distributed Active Archive Center, accessed October 2, 2019, at https://doi.org/10.3334/ORNLDAAC/1219.

U.S. Army Corps of Engineers, 2021a, Fact Sheet: Rio Grande Basin (Section 729), U.S. Army Corps of Engineers, accessed May 11, 2021, at https://www.spa.usace.army.mil/ Media/Fact-Sheets/Fact-Sheet-Article-View/Article/479085/ rio-grande-basin-section-729/.

U.S. Army Corps of Engineers, 2021b, Cochiti Dam and Lake, U.S. Army Corps of Engineers, accessed May 11, 2021, at https://www.spa.usace.army.mil/Missions/Civil-Works/ Recreation/Cochiti-Lake/.

U.S. Census Bureau, 2018, City and town population totals-2010-2017: U.S. Census Bureau, accessed June 16, 2020, at https://www.census.gov/data/tables/time-series/ demo/popest/2010s-total-cities-and-towns.html.

U.S. Department of Agriculture [USDA], 1970, Irrigation water requirements: Publisher, U.S. Department of Agriculture, Soil and Conservation Service, Technical Release No. 21, p. 88.

U.S. Department of Agriculture [USDA], 2015, quick stats: U.S. Department of Agriculture, National Agricultural Statistics Service, accessed December 21, 2015, at https://quickstats.nass.usda.gov/.

U.S. Department of Agriculture [USDA], 2017, NAIP Imagery: United States Department of Agriculture Farm Service Agency, accessed August 20, 2017, at https://www.fsa.usda.gov/programs-and-services/ aerial-photography/imagery-programs/naip-imagery/
U.S. Geological Survey, 2018, USGS 08330000 Rio Grande at Albuquerque, in USGS water data for the Nation: U.S. Geological Survey National Water Information System database, accessed November 8, 2018, at https://doi.org/10.5066/F7P55KJN. [Site information directly accessible at https://waterdata.usgs.gov/nwis/ inventory?agency_code $=$ USGS\&site_no $=08330000$.]

Van Ness, M., 2012, The early cultural history San Luis Valley-South Central Colorado: U.S. Fish and Wildlife Service, accessed October 31, 2018, at https://www.fws.gov/ mountain-prairie/refuges/documents/San\%20Luis\%20 Valley\%20Complex\%20-\%20Cultural\%20History.pdf.

Water Technology, 2019, San Juan-Chama drinking water project, New Mexico: Water Technology, accessed June 27, 2019, at https://www.water-technology.net/projects/san_juan/.

Water Availability and Use Science Program, 2020, National water census - Interactive data visualization of U.S. water budgets: U.S. Geological Survey, accessed August 18, 2020, at https://www.usgs.gov/mission-areas/water-resources/ science/water-availability-and-use-science-program -national-water?qt-science_center_objects $=0 \# q$ t-science _center_objects.

World Population Review, 2018, Population of cities in Mexico-2020: World Population Review, accessed November 1, 2018, at http://worldpopulationreview.com/ countries/mexico-population/cities/.

World Weather Online, 2020, Fort Quitman monthly climate averages: World Weather Online, accessed April 3, 2020, at https://www.worldweatheronline.com/ fort-quitman-weather-averages/texas/us.aspx.

For more information concerning the research in this report, contact the Director, USGS Colorado Water Science Center Box 25046, Mail Stop 415

Denver, CO 80225

(303) 236-4882

Or visit the Colorado Water Science Center website at

https://www.usgs.gov/centers/co-water 


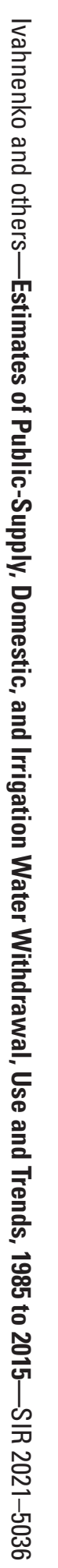

